\title{
The Complexity of Tobacco and Tobacco Smoke*
}

\author{
Presented in part as the CORESTA Prize speech at the Plenary Session of the 2010 CORESTA Congress, Edinburgh, \\ Scotland, September 16
}

by

Thomas A. Perfetti ${ }^{1}$ and Alan Rodgman ${ }^{2}$

${ }^{1}$ Perfetti and Perfetti, LLC, 2116 New Castle Drive, Winston-Salem, NC 27103-5750, USA

22828 Birchwood Drive, Winston-Salem, NC 27103-3410, USA

\section{SUMMARY}

Tobacco and tobacco smoke are both complex mixtures. We previously reported 8430 unique chemical components identified in these complex mixtures but two years later our updated number was 8889. Addition of unlisted isomers raised these numbers to 8622 and 9081 , respectively. Our previous number of 4994 identified tobacco components is now 5229; our previous number of 5315 identified tobacco smoke components is now 5685. An operational definition of a complex mixture is as follows: A complex mixture is a characterizable substance containing many chemical components (perhaps thousands) in inexact proportions. Detailed knowledge of the amount and type of each component within the substance is uncertain even with today's analytical technology. Although it has been estimated that as many as 100000 components are present in these complex mixtures, their analyses indicate that the vast majority of the mass of each of these complex mixtures accounts for the 8430 compounds reported previously. Over $98.7 \%$ of the mass of tobacco has been accounted for in terms of identified components in tobacco. Greater than $99 \%$ of the mass of whole smoke has been accounted for based on identified chemical components. Certainly, many more tobacco and tobacco smoke components are present in these complex mixtures but the total mass of these components obviously is quite small.

One of the significant challenges we face as a scientific community is addressing the problems of determining the risk potential of complex mixtures. Many issues are associated with toxicological testing of the complex mixture of tobacco smoke. Conducting valid experiments and interpreting the results of those experiments can be quite difficult. Not only is the test agent a complex mixture but also the tests are performed on species that have complicated life-processes. Interpretations of test results are often paradoxical. Significant progress has been made in the toxicological evaluations of complex mixtures in the last 80 years. The challenges we face in terms of testing the biological properties of tobacco smoke are substantial. The statement by DIPPLE et al. in their summary of the research on polycyclic aromatic hydrocarbons from the 1930s through 1980 is equally true today for the cigarette smoke situation:

...many important questions remain unanswered

...many questions persist despite the considerable progress that has been made.

[Beitr. Tabakforsch. Int. 24 (2011) 215-232]

\section{ZUSAMMENFASSUNG}

Tabak und Tabakrauch sind beides komplexe Mischungen. Wir haben kürzlich berichtet, dass in diesen beiden komplexen Mischungen 8.430 verschiedene chemische Verbindungen aufzufinden sind, zwei Jahre später hatte sich diese Zahl auf 8.889 erhöht. Das Hinzufügen von ungelisteten Isomeren lässt diese Zahlen auf 8.622 bzw. 9.081 ansteigen. Die Zahl der im Tabak identifizierten Verbindungen hat sich von 4.994 auf 5.229 erhöht, die ursprünglich von uns für den Tabakrauch angeführte Anzahl von 5.315 identifizierten Verbindungen stieg auf 5.685. Eine Arbeitsdefinition für eine komplexe Mischung ist folgende: Eine komplexe Mischung ist dadurch gekennzeichnet, dass sie eine Vielzahl von chemischen Verbindungen (vielleicht tausende) in nicht genau festgelegten Proportionen enthält. Detailliertes Wissen über die Menge und den Typus jeder einzelnen Verbindung innerhalb der Mischung ist nicht sicher, auch im Hinblick auf die heute zur Verfügung stehende chemischanalytische Technik. Obwohl angenommen wird, dass mehr 
als 100.000 Einzelverbindungen in diesen komplexen Mischungen vorhanden sein könnten, zeigen die chemischanalytischen Untersuchungen dieser komplexen Mischungen, dass die 8.430 Einzelverbindungen, die wir ursprünglich angeführt hatten, gewichtsmäßig den überwiegenden Anteil darstellen. Über 98,7\% der Tabakmasse setzen sich aus den bekannten Komponenten zusammen. Mehr als 99\% der Masse des Gesamtrauches stellen identifizierte chemische Verbindungen dar. Es ist sicher, dass viel mehr Substanzen in den komplexen Mischungen Tabak und Tabakrauch vorhanden sind, aber die Gesamtmasse dieser Verbindungen ist offensichtlich sehr klein.

Eine der wichtigsten Herausforderungen, die wir für die Wissenschaft generell sehen, sind die Fragen und Probleme, die sich bei der Bestimmung des Risikopotentials von komplexen Mischungen ergeben. Eine Vielzahl von Fragen sind mit der toxikologischen Testung der komplexen Mischung "Tabakrauch" verbunden. Die Durchführung valider Untersuchungen und die Interpretation ihrer Ergebnisse können schwierig sein. Nicht nur der zu prüfende Tabakrauch ist eine komplexe Mischung, auch die Untersuchungen selbst werden an Spezies durchgeführt, die mit komplizierten Lebensprozessen behaftet sind. Die Interpretation der erhaltenen Untersuchungsergebnisse führt häufig zu widersprüchlichen Schlussfolgerungen. Bedeutende Fortschritte in der toxikologischen Bewertung komplexer Mischungen wurden in den letzten 80 Jahren erzielt. Wir sehen die Herausforderung, die bei der Testung der biologischen Eigenschaften des Tabakrauchs gegeben sind, als beträchtlich an. Die Aussage, die DiPPLE und Mitarbeiter in der Zusammenfassung ihrer fünfzigjährigen Foschungsarbeiten über polyzyklische aromatische Kohlenwasserstoffe (von 1930 bis 1980) getätigt haben, ist heute noch bezüglich der gegebenen Situation beim Zigarettenrauch wahr:

"...viele wichtige Fragen bleiben unbeantwortet

...viele Fragen bleiben bestehen, trotz der beachtlichen

Fortschritte, die gemacht wurden."

[Beitr. Tabakforsch. Int. 24 (2011) 215-232]

\section{RESUME}

Le tabac et la fumée de tabac sont l'un et l'autre des mélanges complexes. Nous avons préalablement établi des rapports sur 8430 composants chimiques uniques identifiés dans ces mélanges complexes. Cependant, deux ans plus tard, notre nombre actualisé est de 8889 . Des isomères supplémentaires non listés ont fait passer ces chiffres à 8622 et 9081 respectivement. Notre chiffre précédent de 4994 composants du tabac identifiés est actuellement de 5229; notre chiffre précédent de 5315 composants identifiés de la fumée de tabac est à présent de 5 685. Une définition opérationnelle d'un mélange complexe est la suivante: un mélange complexe est une substance caractérisable contenant de nombreux composants chimiques (éventuellement des milliers) dans des proportions inexactes. La connaissance détaillée de la quantité et du type de chaque composant au sein de la substance est incertaine même avec les technologies analytiques actuelles. Bien qu'il ait été estimé que jusqu'à 100000 composants sont présents dans ces mélanges complexes, leur analyse indique que la masse de chacun de ces mélanges complexes est en grande partie constituée par les 8430 composés mentionnés précédemment. La masse de tabac était constituée à plus de 98,7\% par les composants identifiés dans le tabac. La masse de la fumée totale à plus de $99 \%$ sur la base des composants chimiques identifiés. De nombreux autres composants du tabac et de la fumée du tabac sont certainement présents dans ces mélanges complexes mais la masse totale de ces composants est manifestement minime.

Faire face aux problèmes de la détermination du risque potentiel de ces mélanges complexes est l'un des défis de taille auxquels nous, membres de la communauté scientifique, sommes confrontés. De nombreux problèmes sont liés à l'analyse toxicologique du mélange complexe de la fumée de tabac. La réalisation d'expériences valides et l'interprétation des résultats de ces expériences peuvent s'avérer assez difficile. Non seulement l'agent d'essai est un mélange complexe, mais les essais sont réalisés sur des espèces qui ont un processus de vie compliqué. Les interprétations des résultats des essais sont souvent paradoxales. Au cours de ces 80 dernières années, des progrès significatifs ont été réalisés dans les évaluations toxicologiques de mélanges complexes. Les défis auxquels nous sommes confrontés lors de l'analyse des propriétés biologiques de la fumée de tabac sont substantiels. La déclaration de DiPPLE et al. dans leur synthèse des recherches sur les hydrocarbures polycycliques des années 1930 jusqu'aux années 1980 est toujours d'actualité quant à la situation de la fumée de cigarette:

...de nombreuses questions importantes restent sans réponse

...de nombreuses questions demeurent en dépit des progrès considérables réalisés.

[Beitr. Tabakforsch. Int. 24 (2011) 215-232]

\section{INTRODUCTION}

Hundreds of scientific articles such as those cited in RODGMAN and PERFETTI (76) contain statements noting that tobacco and tobacco smoke are complex mixtures. This is an accurate statement. An early definition of the complexity of tobacco smoke was that of OSBORNE, ADAMEK, and HOBBS in 1956 (70):

Cigarette smoke composed as it is...of a complex mixture of substances derived from the combustion and pyrolysis of the cigarette...

Although there are hundreds of examples of complex mixtures in the literature, it is difficult to find a precise definition of a complex mixture. For our purpose an operational definition of a complex mixture is as follows:

A complex mixture is a characterized substance containing a set of many chemical components (perhaps thousands) in inexact proportions. Detailed knowledge of the amount and type of each chemical within the substance is uncertain with today's analytical technology. These substances are natural or artificial in origin and can be in the form of gases, liquids, and/or solids. Urban air, automobile exhaust, wood smoke, plant extracts, coal tar, humus, etc. are often cited examples of complex mixtures.

Some have alluded to or emphasized that these unique mixtures are primarily complex, i.e., these mixtures of chemicals are just too multifarious, too difficult to completely understand, or so complicated and/or convoluted that the normal individual could not possible comprehend the totality of the concept or composition of the mixture. This was never the intent of the definition of a complex mixture, 
but nevertheless, some have implied that this multifaceted conglomeration of chemical components in tobacco and tobacco smoke is too difficult to explain and understand. OSBORNE, ADAMEK, and HOBBS (70) were perhaps the first to recognize and publish that tobacco smoke was a complex mixture. The concept that tobacco smoke was a complex mixture was not generally espoused by the Tobacco Industry in the 1950s through the mid-1970s. Prior to the 1950 s, coal tar was designated as a complex mixture. It was also known to have carcinogenic properties. Many of the larger tobacco companies did not want tobacco smoke classified as complex mixtures because of any possible negative similarities that could be drawn between coal tar and tobacco smoke. By the mid-1970s, nearly all companies recognized that tobacco and tobacco smoke were complex mixtures. Numerous tobacco companies began to catalogue the identified components of tobacco and tobacco smoke during the late 1950s. Slowly these catalogues grew in size. By the 1980s, some of the catalogues contained thousands of components. Although companies like Philip Morris and R.J. Reynolds Tobacco Company (RJRT) were cataloguing the published components of tobacco and tobacco smoke, few outside the Tobacco Industry knew of their efforts. It was not until after the Tobacco Master Settlement Agreement was signed in 1998 that public access to most of the internal documents from the major U.S. Tobacco Industry companies was made available through organizations like the Legacy Tobacco Documents Library (http://legacy.library.ucsf.edu, accessed 05/03/ 2011). In the tobacco document databases, tables of identified tobacco and tobacco smoke components can be found. An excellent example of such a catalogue of tobacco and tobacco smoke components is that by RJRT (92). Use of these catalogues was often tedious. What was needed to illustrate that tobacco and tobacco smoke were complex mixtures was a well-organized, easy-to-use text that would provide documentation of the thousands of chemical components identified in tobacco and tobacco smoke.

In 2008, Rodgman and Perfetti (76) co-authored a text on the chemical components in tobacco and tobacco smoke. One of their objectives was to provide specific information on all of the identified chemical components in the complex mixtures of tobacco and tobacco smoke. Their text has not redefined tobacco and tobacco smoke from a complex mixture to a defined mixture but has added scientific substantiation to the nature of these complex mixtures. Simply, their text has attempted to illustrate the complexity of tobacco and tobacco smoke. The text provides the reader with an historical perspective on the identification of thousands of chemical components in tobacco and tobacco smoke, it contains reviews of all known and identified classes of chemical components in tobacco and tobacco smoke, and it provides thousands of accessible references on identified chemical components in tobacco and tobacco smoke. Also provided are references and discussions of one of the major problems with a complex mixture, i.e., the extrapolation of a biological property found in experimental studies with an individual compound in the mixture to the property of that component in a mixture which may contain components that either enhance or offset the experimentally observed biological property of the individual component. Even though tobacco and tobacco smoke are complex mixtures, they are not incomprehensible. The RODGMANPERFETTI text provides a meaningful basis to begin to understand the magnitude and character of the complex mixtures of tobacco and tobacco smoke.

Tobacco and tobacco smoke are among the most extensively studied complex mixtures. As analytical technology improves, it is hoped that one day the complex mixtures of tobacco and tobacco smoke can be reclassified as defined mixtures. With the completion of the Tobacco Genome Project, literally millions of protein fragments have been collected from tobacco and catalogued (69a). Full chemical identification of these protein fragments will take years of work. Today, over 30000 enzymes are known to participate in plant growth and regulation of tobacco. In terms of tobacco smoke, oxidation, reduction, addition, condensation, hydrogenation, pyrolysis, decarboxylation, and dehydration are but a few of the many chemical reactions known to be involved in tobacco pyrolysis and combustion. Additionally, there are ageing effects and artifact formation that can occur during the sampling and testing of cigarette smoke (6). These reactions are capable of producing hundreds of thousands of reaction products. The limiting factor in the discovery and identification of additional chemical components in tobacco and tobacco smoke was the early analytical technology but this was changed significantly over the years by the development of new and ever-improved analytical technologies.

Since the 1954 listing of fewer than a hundred tobacco smoke components by KOSAK (56), various investigators have estimated from gas chromatographic scans that for each component identified in tobacco smoke there are five to twenty components present at extremely low percigarette-yields that have not yet been identified. Thus, as noted by WAKEHAM (90) in 1971 and 1972 when the identified tobacco smoke components numbered about 1350:

Gas chromatographic scans indicate there are many more, probably over ten thousand, possibly even a hundred thousand [tobacco smoke components].

GROB (39), one of the pioneers of the use of glass capillary gas chromatography in tobacco smoke composition studies, as well as other tobacco smoke investigators, also noted that the number of peaks, each of which represented at least one component, in the chromatographic scans far exceeded the number of identified components.

If it were not for scientists' curiosity and the tremendous advances in analytical chemistry over the last 50 to 60 years, the need for the catalogue of components in tobacco and tobacco smoke (76) would not have been critical. As analytical technology advances, surely thousands of new chemical components in tobacco and tobacco smoke will be added to the listings found in the RODGMAN-PERFETTI text. In 1988, the National Research Council (NRC) published a book dealing with the toxicological testing of complex mixtures (68). Testing the toxic effects of single compounds is a relatively straightforward process conducted by toxicologists. However, many substances that humans have interaction with are complex mixtures (4), e.g., mainstream, sidestream and environmental tobacco smoke.

There are thousands of known cigarette smoke components and no doubt thousands more that are at levels too small to be analytically determined by today's analytical methodologies. Cigarette mainstream smoke (MSS) contains com- 
pounds that have been classified by the International Agency for Research on Cancer (IARC) as carcinogenic, possibly carcinogenic, and probably carcinogenic (designated $1 \mathrm{~A}, 2 \mathrm{~A}, 2 \mathrm{~B}$, respectively) when evaluated as single compounds (50a). The additive effect of each of these individual smoke components when taken together presents a considerable negative toxicological effect. However, cigarette MSS also contains numerous anticarcinogens, antimutagens, antioxidants, and vitamins. It is not rational to ignore the presence and potential interactions of the thousands of other components in a complex mixture when evaluating the toxicological effects of tobacco smoke.

One of the significant challenges we face as a scientific community is addressing the problems of identification, classification, and quantification of components within complex mixtures, and the determination of the risk potential of complex mixtures. There are numerous issues associated with testing the toxicity of cigarette smoke to humans in understanding the complex nature of tobacco and tobacco smoke (factors influencing total and individual component smoke yields and the interaction of smoke components within this complex mixture). At present, there are few if any standardized, validated, or otherwise officially sanctioned toxicological assays for the testing of tobacco smoke. Much progress has been made with the development of new and improved toxicological analyses associated with complex mixtures (in general) but until the many issues associated with the testing and interpretation of data are fully resolved (if possible), the designation of individual chemical components of tobacco or tobacco smoke as carcinogenic, possibly carcinogenic, and probably carcinogenic by IARC (50a) falls short in its representation of the toxicological risk assessment of individual tobacco or smoke components that are present within these complex mixtures.

\section{TOBACCO}

In the last 90 years, tobacco scientists have spent considerable time and effort determining and reporting on the chemical composition of tobacco. The number of components identified in various tobacco types increased substantially during the 1950s, 1960s, and 1970s both within and outside the Tobacco Industry. The purpose of such studies was essentially twofold: To define the tobacco components that 1) provided taste and aroma to the smoke to render it acceptable to the consumer and 2) were precursors of the smoke components asserted to be responsible for the health problems induced by tobacco smoke.

One of the first attempts at estimating the mass balance of the major and minor constituents of tobacco was that of HoBBs in 1972 (45). HoBBs stated the following in his review:

In order to understand; even approximately, the bearing of the various physicochemical processes on the character of the generated (smoke) aerosol it is essential to know in some detail the composition of the tobacco from which the aerosol is produced... It will be recognized that the use of different blending quantities of the several varieties of tobacco, or of different processing methods can markedly influence the quantitative composition of (tobacco),... but the differences are likely to be more quantitative than qualitative.
In his review, HOBBS included a figure illustrating the approximate chemical composition of blended cigarette tobacco. Figure 1 is a representation of those same data.

The data that HoBBS used were collected over many years by scientists at Liggett and Myers Tobacco Company. HOBBS' data were subsequently reproduced by GREEN (36, 37 ), in tabular form, see Table 1. HoBBS' original figure showed the approximate chemical composition of blended cigarette tobacco (at $\sim 12 \%$ moisture). The data from GREEN $(36,37)$ were calculated on a dry weight basis.

The data in Table 1 are shown in three columns. The original data by HoBBS (45) are in the second column. HOBBS' data included water, humectants, and flavorants on the tobacco. Column three is the same data as in column two but the data were recalculated to remove water, the added humectants, and the applied flavorants. As can be seen in column three, the carbohydrates (sugars, celluloses, pectic substances, starch and pentosans) represent nearly $41 \%$ of the dry weight of tobacco. Lignin accounts for about $4 \%$ of the weight.

The tobacco protein and amino acids represent about $10 \%$ of the dry tobacco weight. The volatile bases and alkaloids make up about $4 \%$ of the tobacco weight. Waxes and resins (the ether extractable portion of tobacco) represent about $10 \%$ of the dry tobacco weight. Metals $(6 \%)$ and inorganic ions $(1.8 \%)$ make up another $7.8 \%$ of the tobacco weight. The phenolics and acids represent about 8 and $11 \%$ of the dry tobacco weight, respectively. Together, these tobacco constituents account for about $96 \%$ of the dry weight of tobacco. HoBBS (45) added a category called "Others" (at about 4\%) which accounted for the remaining unaccounted for weight. Much of the "Others" category was believed to be composed of dirt, sand and other intractable materials. To date, as indicated in 2008 in the Alphabetical Component Index of RoDGMAN and PERFETTI (76), 4994 separate components had been identified in tobacco, the present number is 5229. Table 2 contains three columns of information: The classification of the tobacco component(s), the average concentration of the component(s) in percent $(\%)$ dry weight of tobacco, and references to tables in RODGMAN and Perfetti (76), GREEN $(36,37)$, and others that support the concentration data. There are four broad classes of tobacco components in Table 2: Hydrocarbons, $O$-containing components, $\mathrm{N}$-containing components, and miscellaneous components.

It must be noted that the majority of compounds found in tobacco are multifunctional. For example, polyfunctional $O$ containing compounds are counted in each functional group, e.g., propanoic acid, 2-hydroxy- (lactic acid) appears in both the alcohol and acid sections; benzoic acid, 4-hydroxy-3methoxy- (vanillic acid) appears in the acid, phenol, and ether sections. In Table 2, care was taken to count each tobacco isolate in only one of the component categories. Every attempt was made not to duplicate any of the 4994 tobacco compounds isolated to date in tobacco. To accomplish this, a method for segregation of compounds, particularly those that were multifunctional, was used. The hierarchical system chosen for the segregation of the chemicals was patterned after the organization of chemical compounds in BEILSTEIN (40). That is, compounds without functional groups such as the hydrocarbons were followed by hydroxyl compounds, oxo compounds, carboxylic acids, amines, etc. 


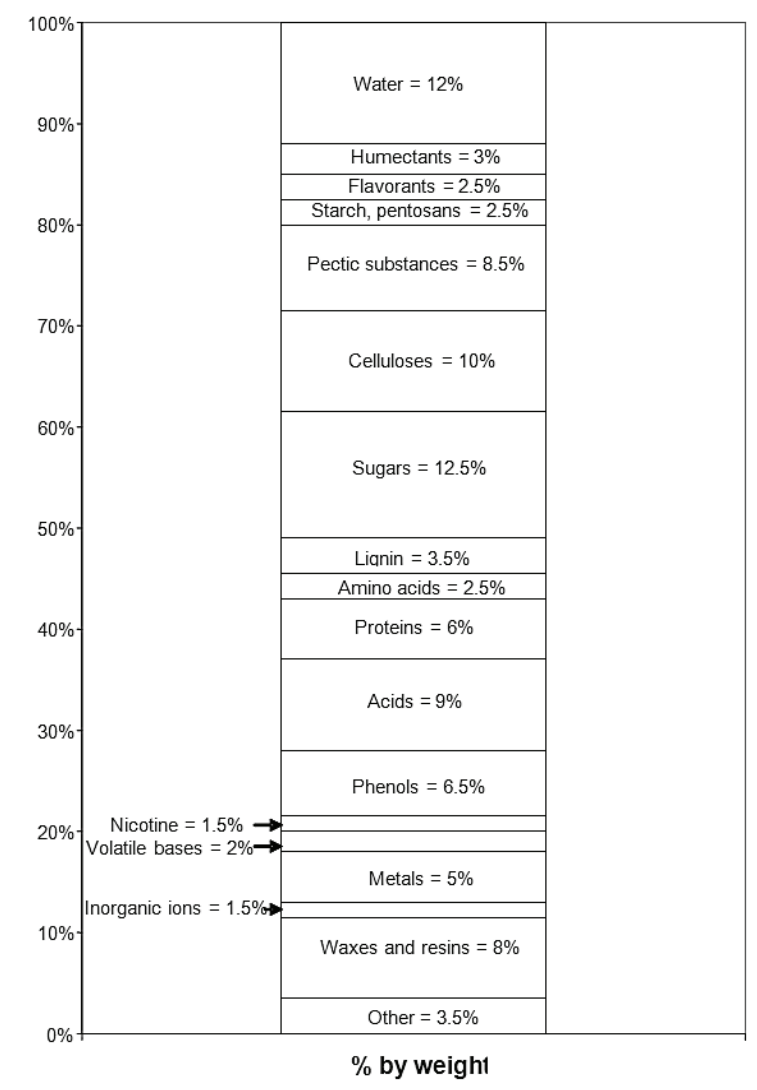

Figure 1. Approximate chemical composition of blended cigarette tobacco (45).

As in BEILSTEIN, the concept of parents and derivatives was followed. For example, phenol would be considered a parent. All substituted phenols were grouped with phenol as derivatives. Although, the strict rules used in BEILSTEIN were not always applied, all of the 4994 compounds were accounted for in a logical manner.

The second column of data in Table 2 lists the average concentration of tobacco compounds. The values listed were obtained from several sources. Primarily, the concentration data were obtained from the text by RODGMAN and Perfetti (76), and scientific papers by $\operatorname{GrEEN}(36,37)$, HoBBS (45), various reports from the RJRT database (www.rjrtdocs.com, accessed 05/03/2011), DEMOLE et al. (17-22) [B], DiCKERSON et al. (23) [F], LEFFINGWELL (60-65) [S], LlOYD et al. (66) [F], ROBERTS et al. $(71,72)$ [B], FUJIMORI et al. (28-32) [O], KIMLAND et al. (52-55) [O], AlmQvist et al. (3) [O], AASEN et al. $(1,2)$ [O], HLUBUCEK et al. (41-44) [O], FUKUZUMI et al. $(33,34)$ [O], ChUMAN et al. (8-16) [O], SCHUMACHER (81-83) [M,O], SCHLOTZHAUER et al. (80), STEDMAN (85), Tso (87, 88 ), WEEKS (91), and from years of personal experience in tobacco science. The cited researchers studied all of the major tobacco types: Flue-cured [F], burley [B], Turkish or Oriental [O], Maryland [M], and several specialty tobacco varieties like Perique and Latakia [S] (see above for designations). In most cases, concentrations of the largest tobacco compounds (those greater than $0.05 \%$ ) were obtained from literature sources. Although in a few cases, particularly those classes of compounds that had low to
Table 1. Approximate chemical composition of blended cigarette tobacco $(36,37,45)$.

\begin{tabular}{l|c|c}
\hline Component & $\begin{array}{c}\text { Wet weight blended } \\
\text { cigarette tobacco (\%) }\end{array}$ & $\begin{array}{r}\text { Dry weight } \\
\text { tobacco (\%) }\end{array}$ \\
\hline Carbohydrates & & \\
$\quad$ Sugars & & \\
Celluloses & 12.5 & 15.15 \\
$\quad$ Pectic substances & 10.0 & 12.12 \\
$\quad$ Starch, pentosans & 8.5 & 10.36 \\
Water & 2.5 & 3.03 \\
Proteins and amino acids & 12.0 & 0.00 \\
$\quad$ Proteins & & \\
$\quad$ Free amino acids & 6.0 & 7.27 \\
Bases & 2.5 & 3.03 \\
$\quad$ Volatile bases & & \\
$\quad$ Nicotine & 2.0 & 2.42 \\
Waxes and resins & 1.5 & 1.81 \\
Metals & 8.0 & 9.69 \\
Phenols & 5.0 & 6.06 \\
Acids & 6.5 & 7.87 \\
Lignin & 9.0 & 10.90 \\
Humectants & 3.5 & 4.24 \\
Flavorants & 3.0 & 0.00 \\
Inorganic ions & 2.5 & 0.00 \\
Others & 1.5 & 1.81 \\
Total & 3.5 & 4.24 \\
\hline & 100.0 & 100.00 \\
\hline
\end{tabular}

a $\quad$ Percent dry weight $=$ minus water, humectants, and added flavorants

very low (0.001-0.000001\%) concentrations, e.g., anhydrides, quinones, oxazoles, aza-arenes, the concentrations were estimated.

The chemical class of compounds in tobacco that has the largest mass is the $O$-containing compounds $(75.70 \%)$, followed by the $N$-containing compounds (12.98\%), miscellaneous compounds (10.61\%, including the category "Others" at $1.21 \%$ ), and finally the hydrocarbons $(0.71 \%)$. Within the $O$-containing components, the largest single subclass of chemical components was the carbohydrates at $40.2 \%$. There are $15.15 \%$ sugars, $12.12 \%$ celluloses, $10.36 \%$ pectins, and $3.03 \%$ starch. There are $9.8 \%$ carboxylic acids and $9.0 \%$ lipids (waxes) and resins in tobacco. In the lipids (waxes) and resins category about $60 \%$ of the weight is lipids and $40 \%$ is resins. The lipids and resins category contains those compounds that prior to the $1950 \mathrm{~s}$ were collected as part of the alcohol-ether-soluble fraction of tobacco. The phenolic category contains $8.3 \%$ of the dry mass of tobacco. About $2.25 \%$ of the weight of the phenolic category is lignin. The remainder of the weight from the $O$ containing class of tobacco is composed of alcohols, phytosterols (and their derivatives), aldehydes, ketones, amino acids, esters, lactones, anhydrides, quinones, and ethers, ranging in levels from 2.0 to $0.0001 \%$ by weight of the dry mass of tobacco.

The two largest categories of compounds that contribute to the $N$-containing class of chemicals found in tobacco are the proteins and amino acids (6.4\%) and the nitrogen heterocyclic compounds, which includes numerous types of 
Table 2. Distribution and approximate composition of tobacco.

\begin{tabular}{|c|c|c|}
\hline Classification of the tobacco component & Average concentration (\%) & $\begin{array}{l}\text { Tables in RODGMAN and PERFETTI (76) } \\
\text { and other references }\end{array}$ \\
\hline \multicolumn{3}{|l|}{ Hydrocarbons } \\
\hline Alkanes & 0.32 & Table I.A-10 \\
\hline Alkenes and alkynes & 0.09 & Table I.B-1 \\
\hline Alicyclics & 0.22 & Table I.C-1 \\
\hline Monocyclic aromatic & 0.08 & Table I.D-1 \\
\hline Polycyclic aromatic & 0.0001 & Table I.E-6, STEPANOV et al. (86) \\
\hline Sub-Totals & 0.71 & \\
\hline \multicolumn{3}{|l|}{ Oxygen-containing components } \\
\hline Alcohols & 1.7 & Table II.A-5 \\
\hline Phytosterols and derivatives & 0.2 & Table II.B-2 \\
\hline Aldehydes & 1.4 & Table III-12 \\
\hline Ketones & 1.8 & Table III-13 \\
\hline Carboxylic acids & 9.8 & Table IV.A-3 \\
\hline Lipids (waxes) and resins & 9.0 & GREEN $(36,37)$ \\
\hline Amino acids & 2.0 & Table IV.B-7 \\
\hline Esters & 0.9 & Table V-3 \\
\hline Lactones & 0.001 & Table VI-2 \\
\hline Anhydrides & 0.0001 & Table VII-1 \\
\hline \multicolumn{3}{|l|}{ Carbohydrates } \\
\hline Celluloses: & & \\
\hline Pectins: & & \\
\hline Sugars: & 40.2 & Iable VIII-3 \\
\hline Starch: & & \\
\hline Total: & & \\
\hline \multicolumn{3}{|l|}{ Phenols } \\
\hline $\begin{array}{ll}\text { Lignin : } & 2.25 \% \\
\text { All other phenolics: } 6.05 \%\end{array}$ & 8.3 & Table IX.A-22 \\
\hline Total: $\quad 8.3 \%$ & & \\
\hline Quinones & 0.001 & Table IX.B-2 \\
\hline Ethers & 0.4 & Table X-2 \\
\hline Sub-Totals & 75.70 & \\
\hline \multicolumn{3}{|l|}{ Nitrogen-containing components } \\
\hline Nitriles & 0.0001 & Table XI-2 \\
\hline Proteins, enzymes, and amines & 6.4 & Tables XII-2, XXII-2 \\
\hline Amides & 0.06 & Table XIII-1 \\
\hline Imides & 0.02 & Table XIV-1 \\
\hline$N$-Nitrosamines & 0.002 & Table XV-8 \\
\hline Nitroalkanes, nitroarenes, and nitrophenols & 0.00001 & Table XVI-1 \\
\hline 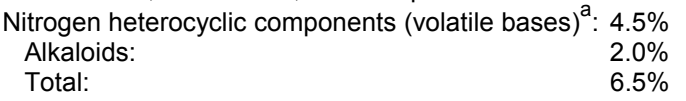 & 6.5 & $\begin{array}{l}\text { Tables XVII.A-1, XVII.A-3, XVII.A-5, XVII.B-1, } \\
\text { XVII.B-3, XVII.B-5 }\end{array}$ \\
\hline Lactams & 0.0001 & Table XVII.C-1 \\
\hline Oxazoles & 0.00001 & Table XVII.D-1 \\
\hline $\begin{array}{l}\text { Aza-arenes, aza-arenes derivatives, and } N \text {-heterocyclic } \\
\text { amines }\end{array}$ & 0.000001 & Tables XVII.E-6, XVII.E-8, XVII.F-8 \\
\hline Sub-Totals & 12.98 & \\
\hline \multicolumn{3}{|l|}{ Miscellaneous components } \\
\hline Sulfur-containing & 0.7 & Table XVIII.A-1 \\
\hline Halogen-containing and fixed gases & 1.5 & Tables XVIII.B-3, XIX-5 \\
\hline Metals, nonmetals, and ions & 7.2 & Tables XX-5, XX-6 \\
\hline Pesticide residues & 0.00001 & Tables XXI-3, BINKLEY (5) \\
\hline All other compounds & $1.205,577$ & \\
\hline Sub-Totals & 10.61 & \\
\hline Grand Total & 100.00 & \\
\hline
\end{tabular}

a Nitrogen heterocyclic components (volatile bases): monocyclic 4-membered $N$-containing ring compounds, monocyclic 5-membered $\mathrm{N}$-containing ring compounds, compounds with multiple monocyclic 5-membered $\mathrm{N}$-containing ring, monocyclic 6 -membered $\mathrm{N}$ containing ring compounds, compounds with a 6-membered $N$-containing ring and a second 5-membered $N$-containing ring, compounds with two or more 6 -membered $N$-containing rings].

tobacco alkaloids and related compounds (6.5\%). The remainder of the weight from the $N$-containing class of tobacco is composed of amides, imides, $N$-nitrosamines, nitroalkanes, nitroarenes, nitrophenols, lactams, oxazoles, and aza-arenes. The mass of all of these remaining $\mathrm{N}$ - containing compounds represents only $0.08 \%$ of the dry weight of tobacco.

The third largest class of components found in tobacco was called "Miscellaneous components" because it includes a broad range of chemical classes: $S$-containing compounds; 


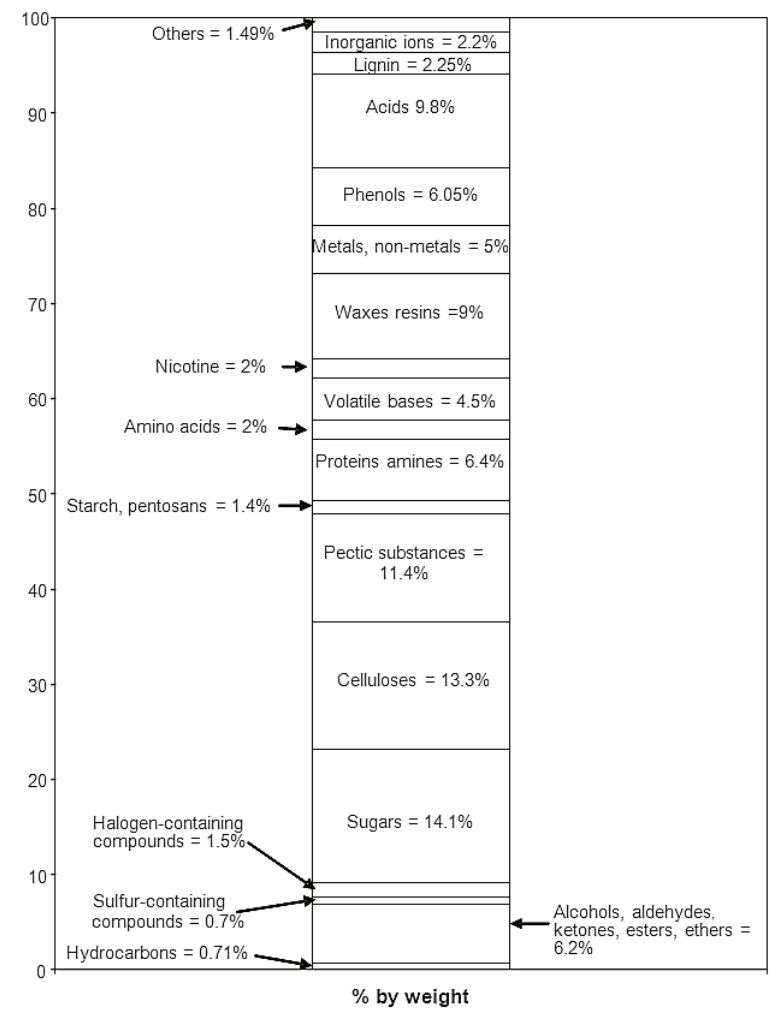

Figure 2. Approximate chemical composition of tobacco.

halogen-containing compounds; metals, nonmetals, and ions; pesticide residues, and the unknown components called "Others". In the third class, the largest contributors to tobacco mass are the metals, nonmetals, and ions (7.2\%). The halogen-containing compounds contribute $1.5 \%$ of the dry tobacco weight. $S$-containing compounds contribute $0.7 \%$ of the dry tobacco weight and approximately $1.21 \%$ of the dry tobacco weight is compounds grouped as "Others". Pesticide residues in tobacco contribute very little to the total tobacco mass $(0.00001 \%)$.

The last class of components identified in tobacco is the hydrocarbons (alkanes, alkenes, alkynes, alicyclics, monocyclic aromatics, and polycyclic aromatics). The total mass of the hydrocarbons is only $0.71 \%$ of the dry weight of tobacco. The largest contributors to mass from this class of components are the alkanes $(0.32 \%)$ and the alicyclics $(0.22 \%)$. The alkenes and alkynes $(0.09 \%)$, the monocyclic aromatics $(0.08 \%)$ and the polycyclic aromatics $(0.000002 \%)$ round out the other hydrocarbons that contribute to the dry weight of tobacco. Figure 2 illustrates the approximate chemical composition of tobacco based on the data of Table 2.

Table 3 is a comparison of the reported concentrations of components found in tobacco from HoBBs (45) compared to similar data entries in Table 2.

There is close agreement between the estimates of the gross compositional tobacco data reported by HoBBS (45) in 1972 versus the data of Table 2. The differences between the HOBBS' data and the data of Table 3 could be from differences in tobacco types tested or from improvements in analytical separation, detection and quantification techno-
Table 3. Comparison of HoвBs (45) data on approximate chemical composition of blended cigarette tobacco compared to similar data of Table 2.

\begin{tabular}{|c|c|c|}
\hline Component & $\begin{array}{l}\text { HOBBS tobacco } \\
\text { data dry weight } \\
\text { basis }(\%)\end{array}$ & $\begin{array}{c}\text { Dry weight tobacco } \\
\text { data from Table } 2 \\
(\%)\end{array}$ \\
\hline \multicolumn{3}{|l|}{ Carbohydrates } \\
\hline Sugars & 15.15 & 14.1 \\
\hline Celluloses & 12.12 & 13.3 \\
\hline Pectic substances & 10.36 & 11.4 \\
\hline Starch, pentosans & 3.03 & 1.4 \\
\hline Subtotal & 40.66 & 40.2 \\
\hline \multicolumn{3}{|l|}{ Proteins and Amino acids } \\
\hline $\begin{array}{c}\text { Proteins, enzymes, } \\
\text { and amines }\end{array}$ & 7.27 & 6.4 \\
\hline Free amino acids & 3.03 & 2.0 \\
\hline Subtotal & 10.3 & 8.4 \\
\hline \multicolumn{3}{|l|}{ Bases } \\
\hline Volatile bases & 2.42 & 4.5 \\
\hline Nicotine & 1.81 & 2.0 \\
\hline Subtotal & 4.23 & 6.5 \\
\hline $\begin{array}{l}\text { Lipids (waxes) and } \\
\text { resins }\end{array}$ & 9.69 & 9.0 \\
\hline Metals & 6.06 & 5.0 \\
\hline Phenols & 7.87 & 6.05 \\
\hline Acids & 10.90 & 9.8 \\
\hline Lignin & 4.24 & 2.25 \\
\hline Inorganic ions & 1.81 & 2.2 \\
\hline Others & 4.24 & 10.6 \\
\hline Total & 100 & 100 \\
\hline
\end{tabular}

a Values in this column represent the same tobacco components cited by HOBBS and are from Table 1. The "Others" value is much higher in column 3 because it includes the "Others" values of Table $2(1.2 \%)$ and all of the smaller tobacco components from Table $2(9.4 \%)$.

logies. The differences in the subtotals for carbohydrates, proteins and amino acids, HoBBs' classification of bases, and most of the other chemical classes are generally different by less than 1-2 weight percent. Under the classification of "Others" for the data of this report (column three), there is about $9.4 \%$ dry weight of tobacco, i.e., $10.6 \%-1.2 \%$ [from Table 2] $=9.4 \%$, that represents hundreds of minor tobacco constituents not accounted for in the components listed in column one of this table but noted in Table 2 . It is quite remarkable how qualitatively similar the data are between the HoBBs' data and those from Table 2. As HoBBS (45) mentioned in 1972 any "differences (in the chemical composition of tobacco) are likely to be more quantitative than qualitative."

\section{TOBACCO SMOKE}

The approximate (and general) composition of cigarette MSS is well-defined. An $85-\mathrm{mm}$ cellulose acetate filtertipped commercial cigarette (65-mm tobacco rod, $20-\mathrm{mm}$ filter tip) whose filler, a typical American blend of tobaccos, 


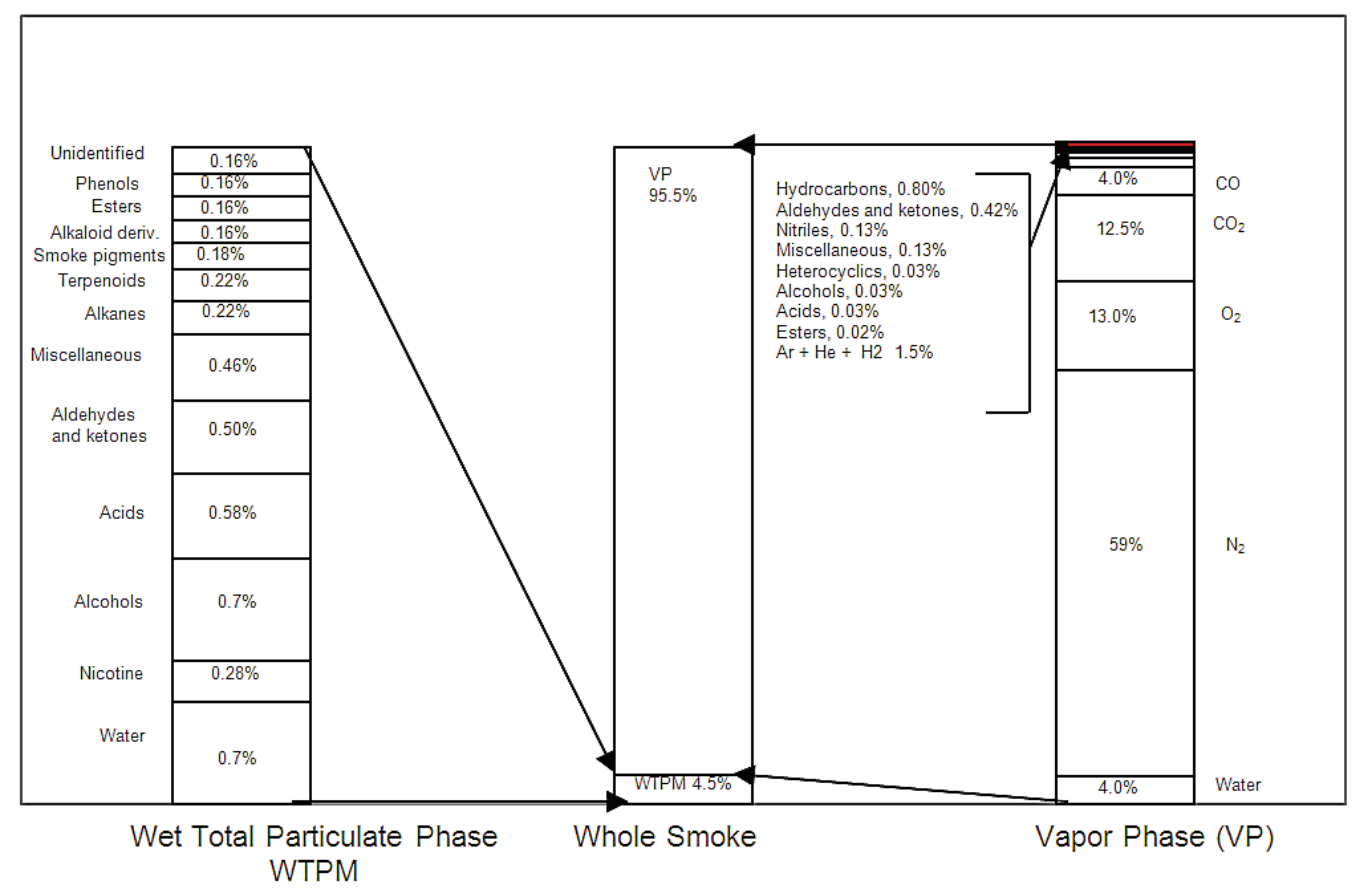

Figure 3. Approximate composition of cigarette mainstream smoke.

weighed approximately $1000 \mathrm{mg}$ was machine smoked with the Federal Trade Commission (FTC)-prescribed smoking parameters $(35-\mathrm{mL}$ puff volume, 2-sec puff duration, 1 puff $/ \mathrm{min} ; 25^{\circ} \mathrm{C} ; 60 \%$ relative humidity; FTC-specified butt length) (27). This cigarette gave approximately $500 \mathrm{mg}$ of total MSS. To separate the tobacco smoke aerosol into its two major phases - the particulate phase and the vapor phase, the smoke was passed through a Cambridge filter pad which retains more than $99.9 \%$ of the particulate phase, defined as total wet particulate matter (WTPM). The vapor phase is that portion of the smoke aerosol which passes through the Cambridge filter pad, and the major portion of its weight is due to the components of air drawn through the cigarette during the smoking process (nitrogen, oxygen, argon, etc.).

The distribution and approximate composition of the total MSS emerging from this cigarette are summarized in Figure 3 (74). The data in Figure 4 represent a consolidation of composition data from several sources including data from RJRT R\&D (57), plus data from KEITH and TESH (51), NORMAN (67), and BrownE et al. (7). To simplify the calculations used to prepare Figure 4, one value was deliberately adjusted slightly for convenience: The total MSS collected actually weighed slightly in excess of $497 \mathrm{mg}$, but the value $500 \mathrm{mg}$ was used to calculate the percentages shown throughout Figure 4.

In addition, no attempt was made with these data to define the degree of partition of some components between the particulate and the vapor phase. Because of their vapor pressure properties, significant quantities of some smoke components are found in both the particulate and vapor phases of cigarette MSS. These include hydrogen cyanide, several of the simple phenols (phenol, $o$-cresol, $m$-cresol, $p$-cresol), and several of the volatile $N$-nitrosamines.

It is evident from the data in Figure 4 that the particulate matter, whether described as WTPM, TPM, or FTC 'tar', comprises less than $5 \%(100 \times 22.5 / 500=4.5 \%)$ of the total MSS emerging from the cigarette. This is true of nearly all commercial U.S. cigarettes no matter what the FTC 'tar' yield. The composition of the MSS vapor phase has been almost completely defined in terms of mass. It is estimated that components representing less than $1 \mathrm{mg}$ of the particulate phase $(5.1 \%$ of the FTC 'tar', less than $0.2 \%$ of the total MSS) remain unidentified. If the number of unidentified components is as high (as many as 100000) as some investigators estimate $(39,90)$, then the level of each unidentified component must average in the low-nanogram range with some present at a picogram level.

The extremely wide variations in the yields of components delivered in the MSS during the smoking of a cigarette have presented unique challenges to those involved not only in the identification of smoke components but also in their quantitation. Table 4 is a minor modification of the initial version presented in 1996 by RODGMAN and GREEN (75). In it, the logarithmic presentation is a more concise depiction of this wide variation in the levels of selected smoke components. For most of the components shown in Table 4, there obviously is a range of values, and the extent of the range for each component is dependent on the cigarette type under study (filtered, non-filtered) and the weight of tobacco consumed during the smoking of the cigarette for the analysis. In general, the locations of the various components on the logarithmic plot have been adjusted for a cigarette yielding about 18 to $20 \mathrm{mg} / \mathrm{cig}$ of FTC 'tar'. If the design of the cigarette has been modified to reduce FTC 'tar' yield, diminution of the yields of the other components will occur but not necessarily to the same extent as the decrease in FTC 'tar' yield. Cigarette design parameters [tobacco rod length and dimensions, filter type and dimensions, filter-tip additives, tobacco blend and weight, processed tobaccos 


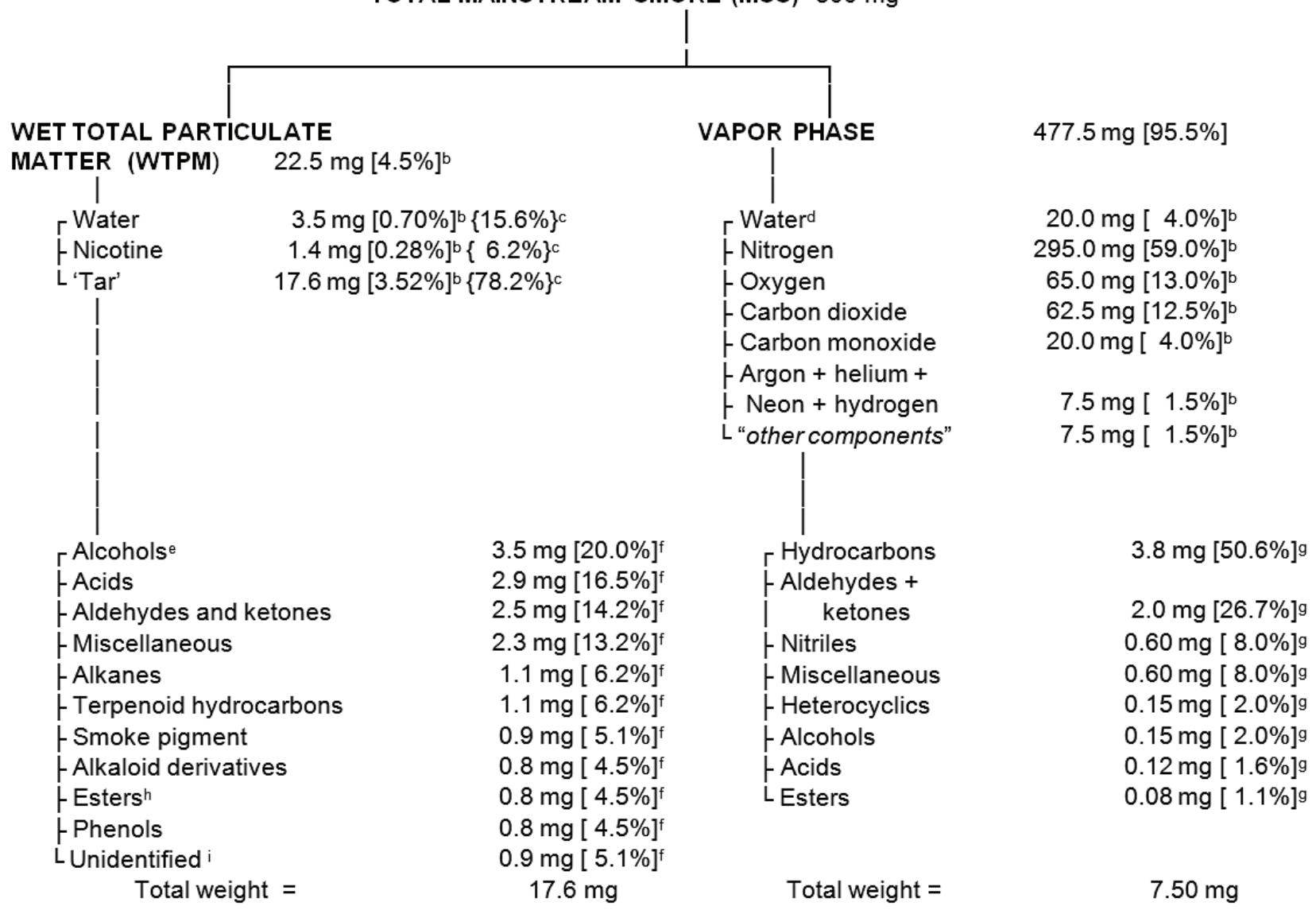

a It is now estimated that over 5,000 components have been identified in MSS from tobacco cigarettes. Some components such as water, the simple phenols, hydrogen cyanide, and the volatile $\mathrm{N}$-nitrosamines are found in both the vapor and particulate phases of cigarette MSS. Hence the total of the number in the two phases appears to exceed the number in the whole.

b Value in brackets represents percent of Total Mainstream Smoke weight, $500 \mathrm{mg}$.

c Value in parentheses represents percent of WTPM, $22.5 \mathrm{mg}$.

d Much of this water is contributed by the air drawn through the cigarette during puffing (35-ml puff, 1-sec duration, 1 puff/min, total puffs $=10)$ in a laboratory whose atmosphere is controlled to the specifications proposed by the $\mathrm{FTC}$; namely, temperature $=25^{\circ} \mathrm{C}$, relative humidity $(\mathrm{RH})=60 \%$.

e This class of compounds includes added humectants (glycerol, propylene glycol) transferred from the tobacco rod to the MSS. The transferred humectants constitute about 10 to $12 \%$ of the FTC 'tar'.

falue in brackets represents percent of FTC 'tar' weight, $17.6 \mathrm{mg}$.

g Value in brackets represents percent of "Other Components" weight, $7.5 \mathrm{mg}$.

$\mathrm{h}$ This class of compounds includes transfer to smoke of some triacetin added to the filter tip plus its degradation products mono- and diacetin.

i There have been various estimates of the number of unidentified components present in extremely small amounts in the FTC 'tar'. Several investigators have estimated the number of unidentified components to range from five to twenty times the number of identified components, i.e., from about 20000 to 100000.

Figure 4. Approximate composition of total cigarette mainstream smoke.

(reconstituted tobacco sheet, expanded tobacco), paper and paper additives, and air dilution (paper porosity and filter perforation)] have profound effects on cigarette MSS yield and composition (Figure 5).

Also shown in Table 4 are those components listed by HOFFMANN and colleagues (46-50) as "tumorigenic components of tobacco and tobacco smoke" and cited as such by the U.S. SURGEON GENERAL (89), the U.S. ENVIRONMENTAL Protection Agency (EPA) (25), and the U.S. OCCUPATIONAL SAFETY AND HeAlth AdMinistration (OSHA) (69). The validity and meaning of their classification of specific tobacco smoke components as tumorigenic have been discussed by RoDGMAN (73).

Yields for the vapor-phase components range from a high of 50-60 mg/cig for carbon dioxide to lows in the nanogram range for vinyl chloride and the volatile nitrosamines such as $N$-nitrosoethylmethylamine. The major portion of the nitrogen ( $\gg 300 \mathrm{mg} / \mathrm{cig}$ ) and oxygen $(\gg 65 \mathrm{mg} / \mathrm{cig}$ ) in MSS is derived from the air drawn through the cigarette during the smoking process. The magnitude of the range of yields for cigarette MSS components is demonstrated by the following: The ratio of the per-cigarette-yield of nitrogen (the most plentiful MSS component shown in Table 4) to that of dibenz $[a, h]$ acridine (the lowest yield shown) is $\gg 3 \times 10^{9}$, i.e., $\gg 300 \mathrm{mg}$ vs. $0.1 \mathrm{ng}$.

As noted previously, it was estimated in the early 1970s by WAKEHAM (90) and GROB (39) from their examination of gas chromatograms that the number of components in 
Table 4. Cigarette mainstream smoke components - logarithmic listing of per cigarette yields.

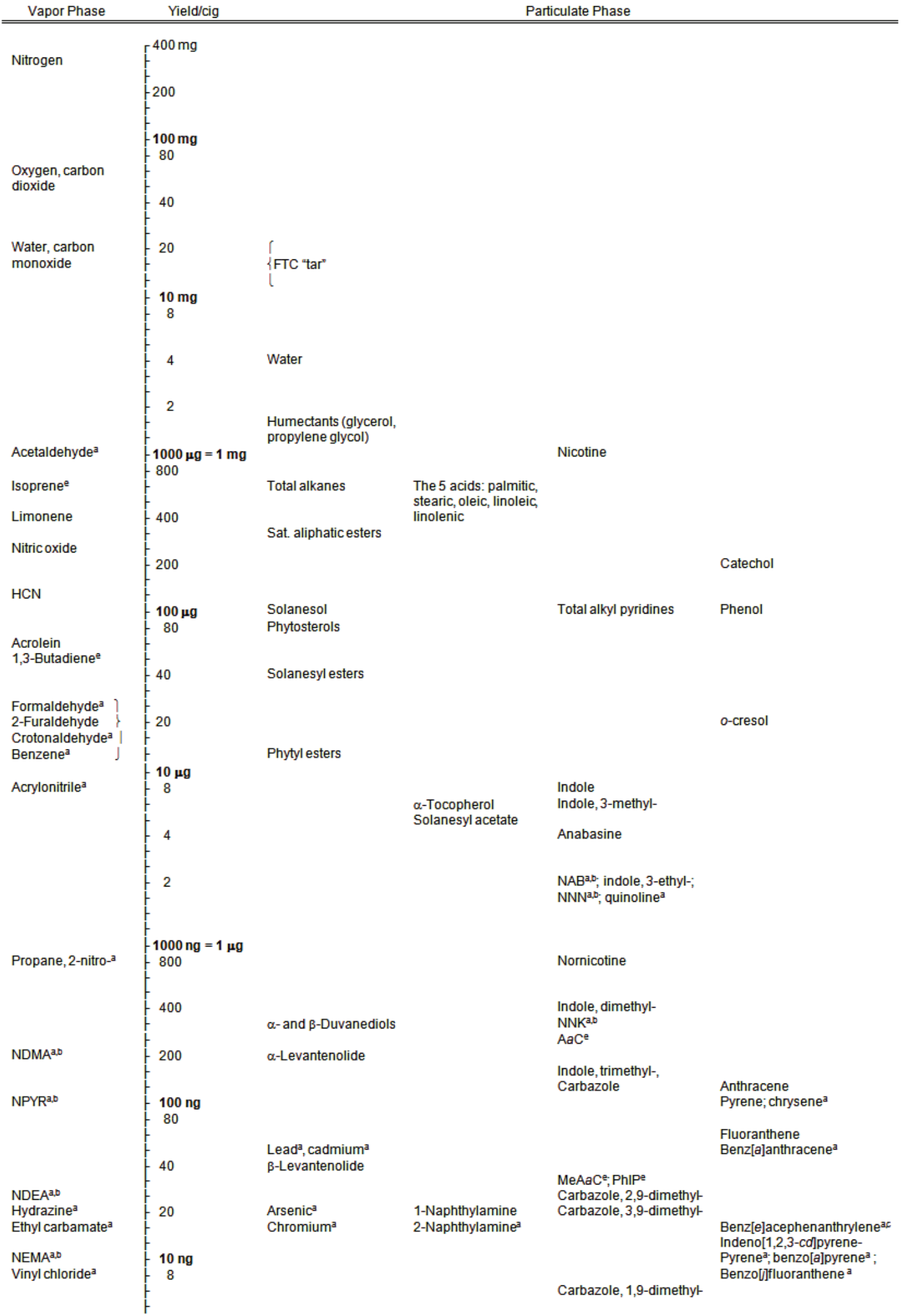




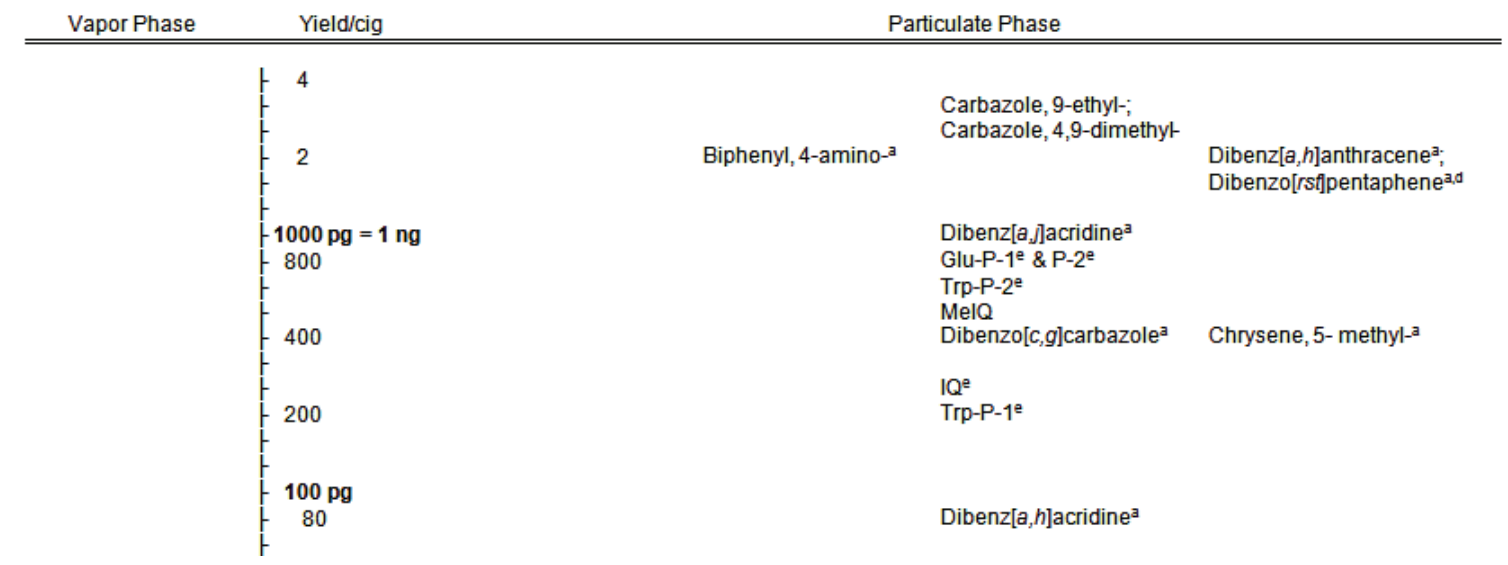

a This tobacco smoke component was included in a list published by HOFFMANN and HECHT (46) in which the component was one of 43 components defined as a "tumorigenic agent in tobacco and tobacco smoke".

b $\quad$ DDEA $=N$-nitrosodiethylamine

NDMA $=N$-nitrosodimethylamine

NEMA $=N$-nitrosoethylmethylamine

NPYR $=N$-nitrosopyrrolidine

$\mathrm{NAB}=N^{\prime}$-nitrosoanabasine

NNK $\quad=4-(N$-methylnitrosamino)-1-(3-pyridinyl)-1-butanone

NNN $=N^{\prime}$-nitrosonornicotine

c Benz[e]acephenanthrylene is the currently accepted name for benzo[b]fluoranthene.

d Benzo[rst]pentaphene is the currently accepted name for dibenzo[a,i]pyrene.

e In a modified list of "tumorigenic agent in tobacco and tobacco smoke," HOFFMANN and HoFFMANN (47) increased the number of components from 43 to 60 and included several of the "cooked food" mutagens as well a several other MSS components (1,3-butadiene, isoprene, etc.).

Trp-P-1 = 3-amino-1,4-dimethyl-5H-pyrido[4,3-b]indole

Trp-P-2 = 3-amino-1-methyl-5H-pyrido[4,3- $b]$ indole

Glu-P-1 = 2-amino-6-methyldipyrido[1,2-a:3',2'-d]imidazole

Glu-P-2 = 2-aminodipyrido[1,2-a:3',2'-d]imidazole

$\mathrm{AaC}=2$-amino-9H-pyrido[2,3-b]indole

$\mathrm{MeAaC}=2$-amino-3-methyl-9H-pyrido[2,3-b]indole

$\mathrm{IQ}=2$-amino-3-methylimidazo[4,5-b]quinoline

PhIP = 2-amino-1-methyl-6-phenylimidazo[4,5- $b]$ pyridine

tobacco smoke far exceeded the number of identified components. The need for analytical methodology to determine smoke components from the high milligram- to the low picogram-yield was one of the driving forces behind many of the developments and improvements in analytical technology for the study of complex mixtures. The trend toward increases in the number of identified tobacco and tobacco smoke components is a direct response to improvements in analytical technology (Figure 6). Prior to 1953 , all of the tobacco and smoke identification work was conducted employing "classical" chemical techniques. From 1953-1960, column chromatography was the new analytical tool that significantly increased the number of identified chemical components in tobacco and smoke. The introduction of gas chromatography (GC), between 1960 and 1970, spurred new interest in analytical identification work. The greatest increase in the number of identified tobacco and smoke isolates came with the advent of glass capillary gas chromatography (GC-GC) and GC-GC coupled with mass spectrometry from 1970 into the mid1980s. Additional analytical improvements from techniques such as high resolution GC (HRGC), high performance liquid chromatography (HPLC), various novel forms of mass spectrometry (MS), and hyphenated analytical tech- niques, e.g., GC-MS, LC-MS, have provided new and valuable tools to the analytical chemist for work on tobacco and smoke component isolation and identification. Despite the many new analytical technologies that have been made available since the late $1980 \mathrm{~s}$, there have been fewer tobacco and tobacco smoke components identified than one might expect. As previously mentioned, it is hoped that this reduced output is due to the difficulties of identifying tobacco and tobacco components that are in the low picogram-yield to fentogram range and not due to lack of interest.

Table 5 shows the distribution of chemical components in tobacco and tobacco smoke. RODGMAN and PERFETTI (76) listed 8430 unique identified components in tobacco and tobacco smoke by 2008. Additionally, they listed 292 partially identified isomers. Thus, the number of identified/partially identified components in tobacco and tobacco smoke totals $8622(8430+292-100)$. The 8622 components were distributed between tobacco, tobacco smoke, or found in both. The number of chemical components that they listed in tobacco was 4994. The number of chemical components that they listed in tobacco smoke was 5315 . There were 1879 chemical components that were found in both tobacco and tobacco smoke. Since 2008 the total 

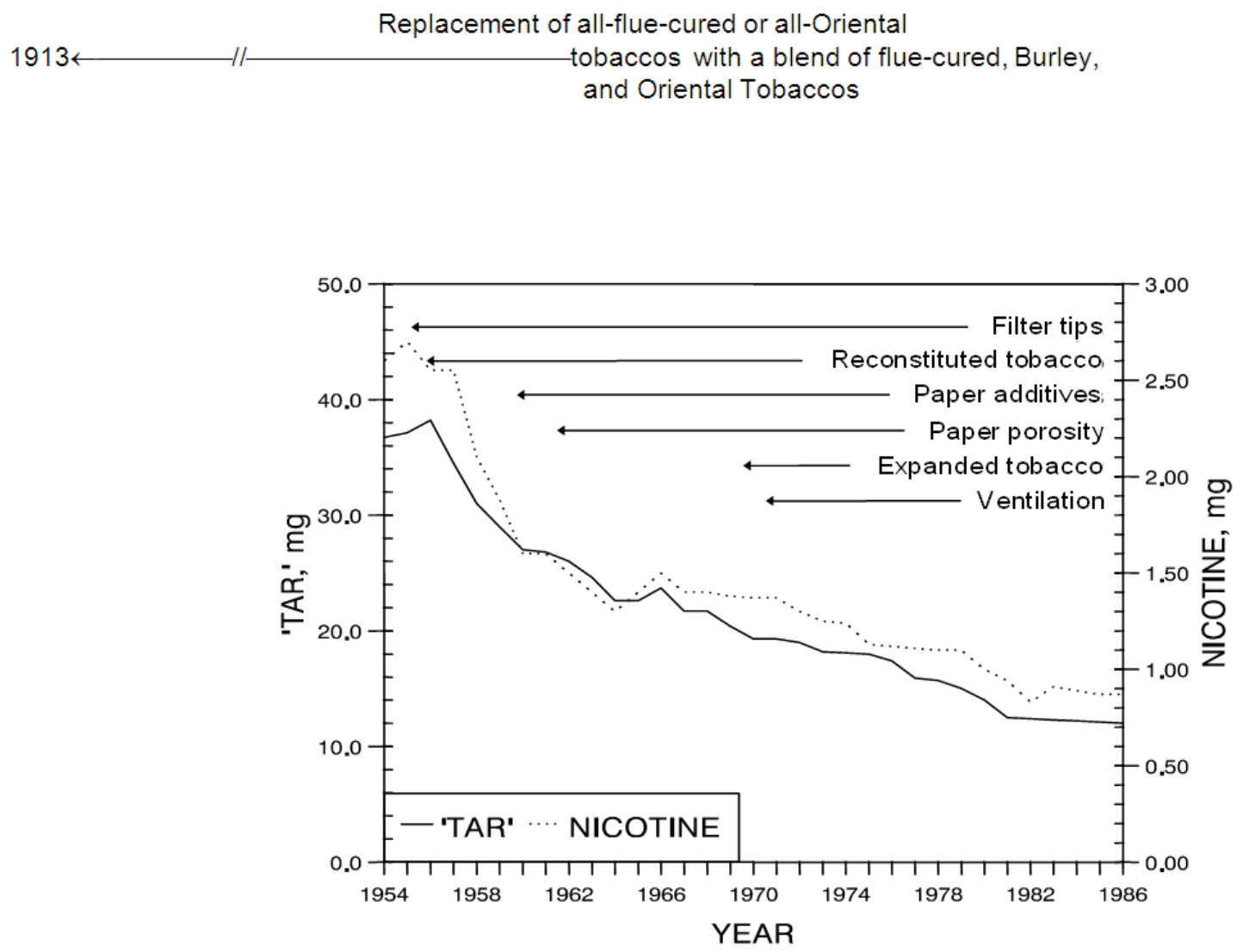

Figure 5. 'Tar' and nicotine yields, sales-weighted average basis, U.S. cigarette products.

number of unique chemical components identified in these complex mixtures has risen to 8889. Addition of unlisted isomers raised this number to 9081 . Our previous number of 4994 identified tobacco components is now 5229; our

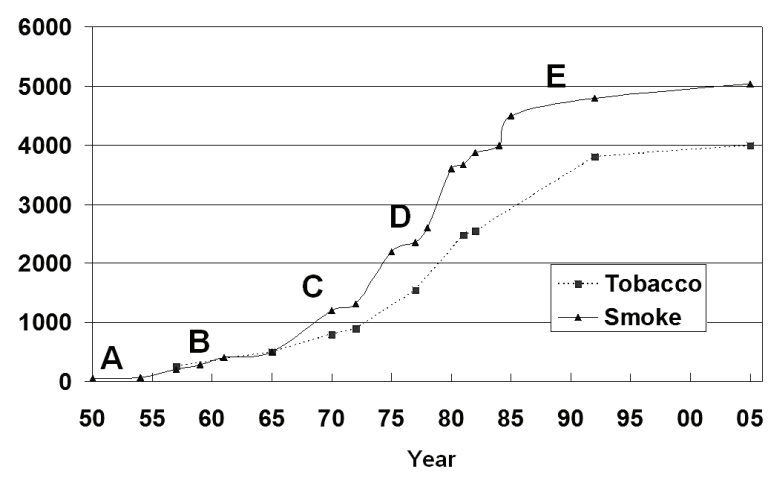

$A=$ prior to 1953: "classical" chemical techniques;

$\mathrm{B}=$ 1953-1960: column chromatography;

$C=$ 1960-1970: gas chromatography;

$\mathrm{D}=1970$ to mid-1970s: glass capillary gas chromatography coupled with mass spectrometry;

$E=$ mid-1970s to date: derivatives for HRGC, HPLC, mass spectrometry.

Figure 6. Number of identified tobacco and tobacco smoke components reported since 1954. previous number of 5315 identified tobacco smoke components is now 5685 .

Table 5 shows 34 classes of chemicals found in tobacco and tobacco smoke. The approximate number of chemical components by class for tobacco and tobacco smoke are shown along with the table in RODGMAN and PERFETTI (76) where additional information can be found on every component.

The text by RoDGMAN and PERFETTI (74) represents a good start for unraveling the mysteries concerning the chemical components of the complex mixtures of tobacco and tobacco smoke. Over $98.7 \%$ of the mass of tobacco has been accounted for in terms of identified components in tobacco. Greater than $99 \%$ of the mass of whole smoke has been accounted for based on identified chemical components. Certainly, there are many more tobacco and tobacco smoke components present in these complex mixtures but the mass of these components must be quite small. For those truly interested and concerned about the mixtures of chemicals that constitute the complex mixtures of tobacco and tobacco smoke, the text by RODGMAN and PERFETTI may be considered:

"an indispensable reference source for tobacco and smoke chemists as well as other scientists involved in the study of tobacco and its products." (38)

RodGMAN and PERFETTI (76) appear to have satisfied one of the goals of their text. No longer can individuals report that the complex mixtures of tobacco and tobacco smoke are too multifarious, too difficult to completely understand, or 
Table 5. Distribution and aproximate number of chemical components in tobacco and tobacco smoke (76).

\begin{tabular}{|c|c|c|c|c|}
\hline Component & Tobacco & \begin{tabular}{|c|} 
Tobacco \\
smoke
\end{tabular} & $\begin{array}{l}\text { Tables in RODGMAN } \\
\text { and PERFETTI (76) }\end{array}$ & Notes \\
\hline \multicolumn{4}{|l|}{ Hydrocarbons } & \multirow{35}{*}{ 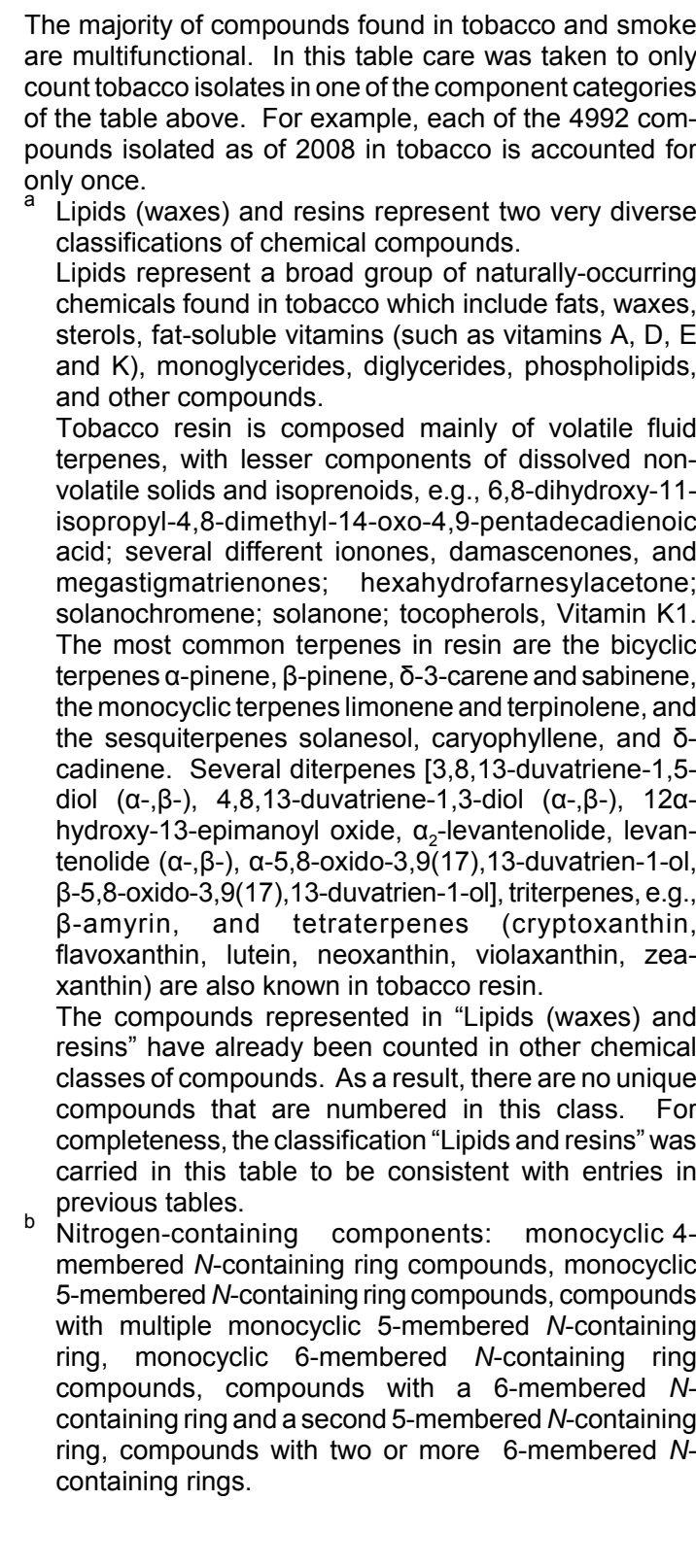 } \\
\hline Alkanes & 20 & 31 & I.A-10 & \\
\hline Alkenes and alkynes & 16 & 320 & I.B-1 & \\
\hline Alicyclics & 42 & 76 & I.C-1 & \\
\hline Monocyclic aromatic & 8 & 58 & I.D-1 & \\
\hline Polycyclic aromatic & 12 & 570 & I.E-6 & \\
\hline Sub-Totals & 98 & 1055 & & \\
\hline \multicolumn{4}{|l|}{ Oxygen-containing components } & \\
\hline Alcohols & 875 & 542 & II.A-5 & \\
\hline $\begin{array}{l}\text { Phytosterols and } \\
\text { derivatives }\end{array}$ & 63 & 9 & II.B-2 & \\
\hline \multirow{3}{*}{$\begin{array}{l}\text { Aldehydes } \\
\text { Ketones } \\
\text { Carboxylic acids }\end{array}$} & 119 & 62 & III-12 & \\
\hline & 418 & 514 & \multirow{2}{*}{$\begin{array}{l}\text { III-13 } \\
\text { IV.A-3 }\end{array}$} & \\
\hline & 368 & 275 & & \\
\hline Lipids (waxes) and resins ${ }^{a}$ & $\ldots$ & $\ldots$ & \multirow{2}{*}{$\stackrel{\cdots}{\cdots}$} & \\
\hline Amino acids & 69 & 1 & & \\
\hline Esters & 388 & 123 & $\begin{array}{l}\text { IV.B-7 } \\
\text { V-3 }\end{array}$ & \\
\hline Lactones & 133 & 118 & $\mathrm{VI}-2$ & \\
\hline Anhydrides & 6 & 7 & VII-1 & \\
\hline Carbohydrates & 230 & 6 & VIII-3 & \\
\hline Phenols & 107 & 363 & IX.A-22 & \\
\hline Quinones & 14 & 26 & IX.B-2 & \\
\hline Ethers & 466 & 392 & \multirow[t]{2}{*}{$\mathrm{X}-2$} & \\
\hline Sub-Totals & 3256 & 2438 & & \\
\hline \multicolumn{4}{|l|}{ Nitrogen-containing components } & \\
\hline Nitriles & 9 & 111 & $\mathrm{XI}-2$ & \\
\hline $\begin{array}{l}\text { Nitriles } \\
\text { Proteins and amines }\end{array}$ & 198 & 177 & $\mathrm{XII-2}$ & \\
\hline Amides & 88 & 106 & XIII-1 & \\
\hline Imides & 19 & 44 & XIV-1 & \\
\hline $\mathrm{N}$-Nitrosamines & 13 & 15 & $X V-8$ & \\
\hline $\begin{array}{l}\text { Nitroalkanes, nitroarenes, } \\
\text { and nitrophenols }\end{array}$ & 17 & 54 & $X V I-1$ & \\
\hline $\begin{array}{l}\text { Nitrogen heterocyclic } \\
\text { components }\end{array}$ & 219 & 642 & $\begin{array}{l}\text { XVII.A-1, XVII.A-3, } \\
\text { XVII.A-5, XVII.B-1, } \\
\text { XVII.B-3, XVII.B-5 }\end{array}$ & \\
\hline Lactams & 20 & 82 & XVII.C-1 & \\
\hline Oxazoles & 14 & 41 & XVII.D-1 & \\
\hline $\begin{array}{l}\text { Aza-arenes, aza-arene } \\
\text { derivatives, and } N- \\
\text { heterocyclic amines }\end{array}$ & 56 & 265 & $\begin{array}{c}\text { XVII.E-6, XVII.E-8, } \\
\text { XVII.F-8 }\end{array}$ & \\
\hline Sub-Totals & 653 & 1537 & & \\
\hline Miscellaneous components & & & & \\
\hline Sulfur-containing & 133 & 99 & & \\
\hline $\begin{array}{l}\text { Halogen-containing and } \\
\text { fixed gases }\end{array}$ & 70 & 133 & XVIII.B-3, XIX-5 & \\
\hline Metal, nonmetals, and ions & 125 & 13 & $X X-5, X X-6$ & \\
\hline Pesticide residues & 188 & 4 & XXI-3 & \\
\hline Enzymes & 469 & 0 & XXII-2 & \\
\hline Free radicals & 0 & 32 & XXVII-1 & \\
\hline Sub-Totals & 985 & 281 & & \\
\hline Grand Total & 4994 & 5311 & & \\
\hline
\end{tabular}


so complicated and/or convoluted that the normal individual could not possible comprehend the totality of the concept or composition of these mixtures.

Investigations of the chemical composition of the tobacco and tobacco smoke complex mixtures although costly, time-consuming, and man-power intensive, are in large-part straightforward. A chemical component is either present or absent. Unfortunately, this is not the case in conducting biological investigations of complex mixtures. Not only is the test agent a complex mixture but also the tests are performed on species that have complicated life-processes. Conducting valid experiments and interpreting the results of those experiments can be quite challenging. One of the significant challenges we face as a scientific community is addressing the problems of determining the risk potential of complex mixtures.

\section{ISSUES WITH TESTING THE BIOLOGICAL PROPER- TIES OF TOBACCO SMOKE}

RODGMAN and GREEN (75) have stated that: "The simplistic dream of both Tobacco Industry and public health scientists is to identify the smoke constituents responsible for adverse health effects and either greatly reduce or eliminate those chemicals to create "less hazardous" products. Whether or not this hope can be made reality is unknown. However, the authors of this review can state with some certainty that the current status of chemical and toxicological sciences does not allow us to demonstrate that any specific chemicals or classes of chemicals present in tobacco smoke are responsible for the health hazards of smoking. Our current belief is in concert with that expressed earlier by the NATIONAL RESEARCH COUNCIL OF THE NATIONAL ACADEMY OF SCIENCES (68) regarding the status of knowledge relating smoke composition with health hazards.

Even after decades of serious investigation, we do not understand the role of tobacco smoke components in producing chronic diseases, such as arteriosclerosis, emphysema and malignant neoplasms. The task of identifying the toxic components is overwhelming and must be considered currently impossible. However, we can identify groups of agents from a knowledge of their chemical similarity to agents generated in a standard control substance."

Extensive articles by RODGMAN et al. (77) and RoDGMAN and GREEN (75) have been written describing numerous hypotheses that have been developed over the past five decades and tested with the technology of the day in attempts to interpret the biological activity of cigarette smoke in relation to the chemistry of this complex mixture, and attempts to quantify the health hazards of smoking, respectively. These articles describe the many issues that scientists face attempting to understand the toxicology of tobacco smoke in general and individual tobacco smoke components.

RODGMAN and GREEN (75) made another very important point that is true today. They stated that:

For most of the last century, the chemistry of tobacco and its smoke has been at the forefront of developing improved smoking products; however, this appears to be changing. The analogy of the forest and trees seems to fit this situation. With chemistry, we can only look at individual MSS or groups of MSS constituents, i.e., the trees, at a time while biological assays within their limitations survey a broad range of effects, i.e., the forest. Ultimately we are not concerned with the health effects related to exposure to individual chemicals in smoke but rather to their effects as a mixture. It is beyond the scope of today's knowledge to predict the toxicology of a complex mixture from data on its individual components.

GoLD et al. (35) in a review in 1998 noted several key points concerning the Carcinogenic Potency Database (CPDB) that AMES and co-workers developed (35a) as a means to screen chemicals for carcinogenic potential.

- Half the chemicals tested in rodent assays are found to be carcinogens; this rate holds whether the chemical is manmade or naturally occurring.

- Among chemicals to which humans are exposed, approximately $99.9 \%$ are naturally occurring.

- Because half the natural chemicals tested are positive, human exposures to rodent carcinogens are likely to be ubiquitous.

- In animal cancer tests, the doses administered are at the maximum tolerated dose (MTD). At the MTD a chemical can cause chronic cell killing and cell replacement in a target tissue which is a cancer risk factor itself.

- In high-dose bioassays, cell division increases mutagenesis and therefore carcinogenesis.

- Extrapolation of cancer potency results from MTD studies to real-life exposures is not scientifically supportable.

- Extrapolation of cancer potency results in rodents to humans cannot be validated.

An example of some of the issues with the simpler case of testing the toxicity of individual chemicals follows.

The standard practice in regulatory risk assessment for chemicals is to extrapolate high-dose animal data to lowdose human exposure without regards to mechanism. If the mechanism of action were known, it is possible that many of the compounds listed in the CPDB database would not be classified as human carcinogens. For example, $D$-limonene which is often cited as a tobacco smoke toxicant and as a rodent carcinogen induces tumors only in male rat kidney tubules with involvement of alpha ${ }_{2 u}$-globulin nephrotoxicity. This mechanism does not appear to be possible in humans (26). Therefore, there is no convincing evidence that $D$ limonene is a human carcinogen when its mechanism of action is considered.

Numerous examples exist in the literature that demonstrate the types of issues experienced in tumorigenic testing of suspected tobacco smoke toxicants in a complex smoke matrix such as cigarette smoke condensate (CSC). For example, RoDGMAN (77) has reviewed the polycyclic aromatic hydrocarbon (PAH) literature vis-à-vis cigarette MSS and reported that "neither a 10-fold increase $(78,79)$ nor a 30 -fold increase $(58,59)$ in the $\mathrm{B}[a] \mathrm{P}$ level in CSC produced an increase in the specific tumorigenicity to mouse skin of the 'spiked' CSC over that of the control CSC." Examples of this type and the published reports of an individual chemical tested to be carcinogenic acting as anticarcinogens in rodents are numerous (76). The difficulties encountered in extrapolating biological activity from cigarette smoke composition provide generally applicable lessons as they are representative of the problems encountered with other complex mixtures. Researchers attempting to assess risk are faced with attempting to interpret data from a number of areas including: Tobacco science; smoke/ aerosol chemistry specific to tobacco; sophisticated analyti- 
cal chemistry applications and techniques for trapping, collecting, separating, and quantifying very specific compounds at nanogram to picogram levels; the properties of the specific compounds, e.g., melting point, boiling point, refractive index, specific gravity, crystalline form; numerous biological testing methodologies; the animal used (species, strain, sex, age); dose; route of administration [inhalation, ingestion, injection (subcutaneous, intravenous, intraperitoneal), skin painting, douching], mode of administration (single vs. multiple doses, neat, in solution, as an aerosol, as a vapor), diet supplied to the animals, cage care; and characteristics of various animal models of tumors and carcinogenesis. The current problems of the effect of the biological testing on interpretation of biological data were originally described in 1941 by SHEAR and LEITER (84).

The challenges we face in terms of testing the biological properties of tobacco smoke are great. The statement by DIPPLE et al. (24) in their summary of the research on PAHs from the 1930s through 1980 is equally true today for the cigarette smoke situation:

...many important questions remain unanswered

...many questions persist despite the considerable progress that has been made.

\section{REFERENCES}

1. Aasen, A.J., J.R. Hlubucek, and C.R. Enzell: New tobacco constituents originating from terpenoid precursors; $9^{\text {th }}$ Internat. Symp. Chem. Natural Products, Ottawa, Ontario, Canada (1974).

2. Aasen. A.J., T. Nishida, C.R. Enzell, and M. Devreux: Tobacco chemistry. 37 . The absolute configuration of prenylsolanone, (9S)-6,12-dimethyl-9-isopropyltrideca-5E,10E,12-trien-2-one. A northunberganoid of Nicotiana tabacum L.; Acta Chem. Scand. B30 (1976) 178-179.

3. Almqvist, S.O., A.J. Aasen, J.R. Hlubucek, B. Kimland, and C.R. Enzell: Tobacco chemistry. 23. Structures and syntheses of four new norisoprenoid furans from Greek Nicotiana tabacum L.; Acta Chem. Scand. B28 (1974) 528-532.

4. Aviado, D.M.: Complex mixtures of tobacco smoke and the occupational environment; Chapter 4 in: Patty's Industrial Hygiene and Toxicology, $4^{\text {th }}$ Edition, Vol. 2, Pt. A, edited by G.D. Clayton and F.E. Clayton, John Wiley and Sons, Inc., New York, NY (1993) 107-148.

5. Binkley, J.: Analysis of pesticides in smokeless tobacco by comprehensive two-dimensional gas chromatography-time of flight mass spectrometry (GC $\times$ GC-TOFMS); LC-GC Chromatography Online, September 1, 2009.

6. Borgerding, M. and H. Klus: Analysis of complex mixtures - Cigarette smoke; Exp. Tox. Pathol. 57 (Suppl. 1), (2005) 43-73.

7. Browne, C.L., C.H. Keith, and R.E. Allen: The effect of filter ventilation on the yield and composition of mainstream and sidestream smoke; $32^{\text {nd }}$ Tobacco Chemists' Research Conference, Program Booklet and Abstracts, Vol. 32, Paper No. 16, 1978, p. 8; CORESTA 1978 Symp., Sofia, Bulgaria, CORESTA
Inf. Bull., Spec. Edition 1978: Paper ST-01, 124; Beitr. Tabakforsch. Int. 10 (1980) 81-90.

8. Chuman, T.: Chemical studies on aroma constituents of Turkish tobacco; Sci. Papers, Cent. Res. Inst., Japan Monopoly Corp. 119 (1977) 45-92.

9. Chuman, T., H. Kaneko, T. Fukuzumi, and M. Noguchi: Isolation of two terpenoid acids 4-isopropyl-7methyl-5E,7-octadienoic acid and 3-isopropyl-6methyl-4E,6-heptadienoic acid from Turkish tobacco; Agr. Biol. Chem. 38 (1974) 2295-2296.

10. Chuman, T., H. Kaneko, T. Fukuzumi, and M. Noguchi: Acidic aroma constituents of Turkish tobacco: Terpenoid acids related to tobacco thunberganoids; Agr. Biol. Chem. 40 (1976) 587-591.

11. Chuman, T., H. Kaneko, and M. Noguchi: The structure of a new terpenoid acid, $1-\xi$-methyl-3- $\xi$ isopropyl-cyclopentane-1- $\xi, 2-\xi$-dicarboxylic acid, isolated from Turkish tobacco; Agr. Biol. Chem. 42 (1978) 203-204.

12. Chuman, T. and M. Noguchi: Isolation of a new terpenoid acid 2-methyl-5-isopropyl-1-cyclopentene-1carboxylic acid from Turkish tobacco; Agr. Biol. Chem. 39 (1975) 567-568.

13. Chuman, T. and M. Noguchi: Isolation of new terpenoid acids (-)-3-methyl-6-isopropyl-9-oxo-2E,4Edecadienoic acid and 3-isopropyl-6-oxo-2Z-heptenoic acid from Turkish tobacco; Agr. Biol. Chem. 39 (1975) 1169-1171.

14. Chuman, T. and M. Noguchi: The structure of a new terpenoic acid, $6(S)$-isopropyl-3 $\xi$-methyl-3 $\xi$-hydroxy9-oxo-4E-decenoic acid, isolated from Turkish tobacco; Agr. Biol. Chem. 40 (1976) 1793-1796.

15. Chuman, T. and M. Noguchi: Acidic aroma constituents of Turkish tobacco; Agr. Biol. Chem. 41 (1977) 1021-1030.

16. Chuman, T., M. Noguchi, A. Ohkubo, and S. Toda: The structure of a novel terpenoid acid, " $\xi$-hydroxy$4 \xi, 9$-dimethyl-6E,9E-dodecadienedioic", isolated from Turkish tobacco; Tetrahedron Lett. 18 (1977) 3045-3058.

17. Demole, E. and D. Berthet: A chemical study of burley tobacco flavour (Nicotiana tabacum L.). I. Volatile to medium-volatile constituents (b.p. $\leq 84 \% 0.001$ Torr); Helv. Chim. Acta 55 (1972) 1866-1882.

18. Demole, E. and D. Berthet: A chemical study of burley tobacco flavour (Nicotiana tabacum L.). II. Mediumvolatile, free acidic constituents (b.p. $\sim 84-114^{\circ} / 0.001$ Torr); Helv. Chim. Acta 55 (1972) 1898-1901.

19. Demole, E. and C. Demole: A chemical study of burley tobacco flavour (Nicotiana tabacum L.). V. Identification and synthesis of the novel terpenoid alkaloids 1,3,6,6-tetramethyl-5,6,7,8-tetrahydroisoquinolin-8-one and 3,6,6-trimethyl-5,6-dihydro-7H-2pyrindin-2-one; Helv. Chim. Acta 58 (1975) 523-531.

20. Demole, E. and C. Demole: A chemical study of burley tobacco flavour (Nicotiana tabacum L.). VII. Identification and synthesis of twelve irregular terpenoid alkaloids related to solanone including 7,8dioxabicyclo[3.2.1]octane and 4,9-dioxabicyclo[3.3.1]nonane derivatives; Helv. Chim. Acta 58 (1975) 1867-1880.

21. Demole, E., C. Demole, and D. Berthet: A chemical 
study of burley tobacco flavour (Nicotiana tabacum L.). III. Structure determination and synthesis of 5-(4methyl-2-furyl)-6-methylheptan-2-one ("solanofuran") and of 3.4.7-trimethyl-1,6-dioxaspiro[4,5]dec-3-en-2one ("spiroxabovolide"). Two new flavor components of burley tobacco; Helv. Chim. Acta 56 (1973) 265-271.

22. Demole, E. and P. Dietrich: A chemical study of burley tobacco flavour (Nicotiana tabacum L.); in: Recent advances in the chemical composition of tobacco and tobacco smoke, edited by J.L. McKenzie, R.M. Ikeda, T.R. Terrill, D.G. Vickroy, and D.B. Walters, Proc. Am. Chem. Soc. Symp., New Orleans, LA (1977) 1-36.

23. Dickerson, J.P., D.L. Roberts, C.W. Miller, R.A. Lloyd, and C.E. Rix: Flue-cured tobacco flavor. II. Constituents arising from amino acid-sugar reactions; Tob. Sci. 20 (1976) 59-63.

24. Dipple, A., R.C. Moschel, and C.A.H. Bigger: Polynuclear aromatic carcinogens; Chapter 2 in: Chemical carcinogens. $2^{\text {nd }}$ edition, edited by C.E. Searle, American Chemical Society Monograph 182, American Chemical Society, Washington, DC (1984) 41-163.

25. Environmental Protection Agency (EPA): Health effects of passive smoking: Assessment of lung cancer in adults and respiratory disorders in children; Draft Document EPA/600/6-90/006A (May 1990).

26. Environmental Protection Agency (EPA): Report of the EPA review workshop on alpha $_{2 \mathrm{u}}$-globulin: Association with renal toxicity and neoplasia in the male rat; US EPA, Washington, DC (1991).

27. Federal Trade Commission: Cigarettes: Testing for tar and nicotine content; Fed. Register 32 (1967) 11178; Pillsbury, H.C., C.C. Bright, K.J. O'Connor, and F.W. Irish: Tar and nicotine in cigarette smoke; J. Assoc. Off. Anal. Chem. 52 (1969) 458-462.

28. Fujimori, T., R. Kasuga, H. Kaneko, and M. Noguchi: A new acetylenic diol, 3-hydroxy-7,8-dehydro- $\beta$ ionol, from burley Nicotiana tabacum; Phytochemistry 14 (1975) 2095.

29. Fujimori, T., R. Kasuga, H. Kaneko, and M. Noguchi: Isolation of $\mathrm{R}(-)$-3-hydroxy- $\beta$-ionone from burley tobacco; Agr. Biol. Chem. 38 (1974) 891-892.

30. Fujimori, T., R. Kasuga, H. Kaneko, and M. Noguchi: Isolation of 3-(4,8,12-trimethyltridecyl)-furan ("phytofuran") from burley tobacco; Agr. Biol. Chem. 38 (1974) 2293-2294.

31. Fujimori, T., R. Kasuga, H. Kaneko, and M. Noguchi: Isolation of 3-hydroxy- $\beta$-ionol from burley tobacco; Agr. Biol. Chem. 39 (1975) 913-914.

32. Fujimori, T., R. Kasuga, H. Matsushita, H. Kaneko, and M. Noguchi: Neutral aroma constituents in burley tobacco; Agr. Biol. Chem. 40 (1976) 303-315.

33. Fukuzumi, T., H. Kaneko, and H. Takahara: Studies on the chemical constituents of tobacco leaves. Part III. Isolation of a (-)-2-isopropyl-5-oxohexanoic acid from Turkish tobacco leaves and absolute configuration of solanone; Agr. Biol. Chem. 31 (1967) 607-610.

34. Fukuzumi, T., H. Takahara, H. Kaneko, and I. Onishi: Studies of the chemical constituents of tobacco leaves.
I. Organic acids in Turkish tobacco; J. Agr. Chem. Soc. Japan 39 (1965) 199-203.

35. Gold, L.S., T.H. Slone, and B.N. Ames: What do animal cancer tests tell us about human cancer risk?: Overview of analyses of the carcinogenic potency database; Drug Metab. Rev. 30 (1998) 359-404.

35a. Gold, L.S. and E. Zeiger: Handbook of carcinogenic potency and genotoxicity databases; CRC Press, Boca Raton, FL (1997); see also Gold, L.S.: Carcinogenic Potency Database (CPDB) http://potency. berkeley.edu/, accessed 05/03/2011.

36. Green, C.R.: Some relationships between tobacco leaf and smoke composition; in: Recent advances in the chemical composition of tobacco and tobacco smoke, edited by J.L. McKenzie, R.M. Ikeda, T.R. Terrill, D.G. Vickroy, and D.B. Walters, Proc. Am. Chem. Soc. Symp., New Orleans, LA (1977) 426-470.

37. Green, C.R.: Tobacco and smoke chemistry; RJRT presentation, March 21, 1984, see www.rjrtdocs.com, 512094044-4155, 504890559-0670, accessed 05/03/ 2011.

38. Green, C.R.: Book review: The chemical components of tobacco and tobacco smoke (Alan Rodgman and Thomas A. Perfetti, CRC Press, Taylor and Francis Group, Boca Raton, Florida, 2008, 1836 pages); Beitr. Tabakforsch. Int. 23 (2009) 227-230.

39. Grob, K.: High resolution g.c. analysis of cigarette smoke; Chem. Ind. 6 (1973) 248-252.

40. Heller, S. R., Editor, The Beilstein Online Database Implementation, content, and retrieval; ACS Symposium Series \#436, American Chemical Society, Washington, DC, 1990.

41. Hlubucek, J.R., A.J. Aasen, S.-O. Almqvist, and C.R. Enzell: Tobacco chemistry. 21. Three new volatile tobacco constituents of probable isoprenoid origin; Acta Chem. Scand. B27 (1973) 2232-2234.

42. Hlubucek, J.R., A.J. Aasen, S.-O. Almqvist, and C.R. Enzell: Tobacco chemistry. 22. Structures and syntheses of a nor- and a seco-terpenoid of the drimane series isolated from tobacco; Acta Chem. Scand. B28 (1974) 18-22.

43. Hlubucek, J.R., A.J. Aasen, S.-O. Almqvist, and C.R. Enzell: Tobacco chemistry. 25. Two new drimane sesquiterpene alcohols from Greek Nicotiana tabacum L.; Acta Chem. Scand. B28 (1974) 289-294.

44. Hlubucek, J.R., A.J. Aasen, B. Kimland, and C.R. Enzell: New volatile constituents of Greek Nicotiana tabacum L.; Phytochemistry 12 (1973) 2555-2557.

45. Hobbs, M.E.: Some physico-chemical aspects of cigarette smoke generation; CORESTA/TCRC Joint Conf., Williamsburg, VA, CORESTA Invited Papers (1972) 53-75.

46. Hoffmann, D. and S.S. Hecht: Advances in tobacco carcinogenesis; in: Chemical carcinogenesis and mutagenesis, edited by C.S. Cooper and P.L. Grover, Springer-Verlag, London, UK (1990) 63-102.

47. Hoffmann, D. and I. Hoffmann: [Chemical studies on tobacco smoke. C.] The changing cigarette: 1950-1995; J. Toxicol. Environ. Health 50 (1997) 307-364.

48. Hoffmann, D. and I. Hoffmann: Tobacco smoke components. Letter to the Editor; Beitr. Tabakforsch. 
Int. 18 (1998) 49-52.

49. Hoffmann, D. and I. Hoffmann: The changing cigarette: Chemical studies and bioassays; Chapter 5 in: Risks associated with smoking cigarettes with low machine-measured yields of tar and nicotine, NCI Smoking and tobacco control, Monograph 13, edited by D.M. Burns and N.L. Benowitz, Bethesda, MD (2001) 159-191.

50. Hoffmann, D., I. Hoffmann, and K. El-Bayoumy: The less harmful cigarette: A controversial issue. A tribute to Ernst L. Wynder; Chem. Res. Toxicol. 14 (2001) 767-790.

50a. International Agency for Research on Cancer (IARC): Evaluation of the carcinogenic risk to humans: Tobacco smoking; IARC, Lyon, France, IARC Monograph 38 (1986).

51. Keith, C.H. and P.G. Tesh: Measurement of the total smoke issuing from a burning cigarette; Tob. Sci. 9 (1965) 61-64.

52. Kimland, B., A.J. Aasen, S.-O. Almqvist, P. Arpino, and C.R. Enzell: Volatile acids of sun-cured Greek Nicotiana tabacum; Phytochemistry 12 (1973) 835-847.

53. Kimland, B., A.J. Aasen, and C.R. Enzell: Tobacco chemistry. 12. Neutral volatile constituents of Greek tobacco; Acta Chem. Scand. 26 (1972) 1281-1284.

54. Kimland, B., A.J. Aasen, and C.R. Enzell: Tobacco chemistry. 10. Volatile neutral constituents of Greek tobacco; Acta Chem. Scand. 26 (1972) 2177-2184.

55. Kimland, B., R.A. Appleton, A.J. Aasen, J. Roeraade, and C.R. Enzell: Neutral oxygen-containing volatile constituents of Greek tobacco; Phytochemistry 11 (1972) 309-316.

56. Kosak, A.I.: The composition of tobacco smoke; Experientia 10 (1954) 69-71.

57. Laurene, A.H.: Personal communication to A.R. (1965).

58. Lazar, P., I. Chouroulinkov, C. Libermann, and M. Guerin: Amounts of 3,4-benzpyrene (3,4-BP) in cigarette smoke condensates and carcinogenicity; $9^{\text {th }}$ Internat. Cancer Cong., Tokyo, Japan (1966).

59. Lazar, P., I. Chouroulinkov, C. Libermann, and M. Guerin: Benzo[a]pyrene content and carcinogenicity of cigarette smoke condensate: Results of short-term and long-term tests; J. Natl. Cancer Inst. 37 (1966) 573-579.

60. Leffingwell, J.C.: Nitrogen components of leaf and their relationship to smoking quality and aroma; Recent Adv. Tob. Sci. 2 (1976) 1-31.

61. Leffingwell, J.C.: Leaf chemistry. A. Basic chemical constituents of tobacco leaf and differences among tobacco types; Chapter 8A in: Tobacco: Production, chemistry and technology, edited by D.L. Davis and M.T. Nielsen, Blackwell Science, Oxford, UK (1999) 265-284; Chemical constituents of tobacco leaf and differences among tobacco types; Leffingwell Reports. 1 (2001) 1-56.

62. Leffingwell, J.C. and E.D. Alford: Phenolic aroma constituents of Kentucky fire cured tobacco; $52^{\text {nd }}$ Tobacco Science Research Conference, Program Booklet and Abstracts, Vol. 52, Paper No. 17, 1998, p. 23, see www.leffingwell.com/firecured.htm, accessed
05/03/2011.

63. Leffingwell, J.C. and E.D. Alford: Volatile constituents of Perique tobacco; Electronic J. Environ. Agr. Food Chem. 4 (2005) 899-915.

64. Leffingwell, J.C. and D. Leffingwell: TCRC Symposium: Chemical and sensory aspects of tobacco flavor - An overview; Recent Adv. Tob. Sci. 14 (1988) 169-218.

65. Leffingwell, J.C., H.J. Young, and E. Bernasek: Tobacco flavoring for smoking products; R. J. Reynolds Tobacco Company, Winston-Salem, NC (1972), see www.rjrtdocs.com 509248328 -8365, accessed 05/03/2011.

66. Lloyd, R.A., C.W. Miller, D.L. Roberts, J.A. Giles, J.P. Dickerson, N.H. Nelson, C.E. Rix, and P.H. Ayers: Flue-cured tobacco flavor. I. Essence and essential oil components; CORESTA 1974 Symp., Montreux, Switzerland (1974); Tob. Sci. 20 (1976) 40-48.

67. Norman, V.: An overview of the vapor phase, semivolatile and nonvolatile components of cigarette smoke; Recent Adv. Tob. Sci. 3 (1977) 28-58.

68. National Research Council (NRC): Complex mixtures: Methods for in vivo toxicity testing; National Academy Press, Washington, DC, 1988.

69. Occupational Safety and Health Administration (OSHA): Indoor air quality; Fed. Reg. 59 (No. 65) (1994) 15968-16039.

69a. Opperman, C., S. Lommel, and the Tobacco Genome Initiative Group: The Tobacco Genome Initiative: Gene discovery, data mining, and implications to plant biology; Recent Adv. Tob. Sci. 33 (2007) 5-14.

70. Osborne, J.S., S. Adamek, and M.E. Hobbs: Some components of gas phase of cigarette smoke; Anal. Chem. 28 (1956) 211-215.

71. Roberts, D.L.: Natural tobacco flavor; Recent Adv. Tob. Sci. 14 (1988) 49-81.

72. Roberts, D.L. and W.A. Rohde: Isolation and identification of flavor components of burley tobacco; Tob. Sci. 16 (1972) 107-112.

73. Rodgman, A.: The composition of cigarette smoke: Problems with lists of tumorigens; Beitr. Tabakforsch. Int. 20 (2003) 402-437.

74. Rodgman, A. and L.C. Cook: The composition of cigarette smoke; Presented at Sigma Xi Meeting, Wake Forest University, Winston-Salem, NC 17 March, 1965, see www.rjrtdocs.com 501521599-1606, accessed 05/03/2011; the American Chemical Society Section Meeting, Columbus, GA, 2 May 1968, and the Chemistry Club, Chemistry Department, Columbus College, Columbus, GA, 2 May 1968, see www.rjrtdocs.com $501521608-1615$, accessed 05/03/2011; and the Central North Carolina Section Meeting, American Chemical Society, Greensboro, NC, 14 October 1969, for presentation text and slides, see www.rjrtdocs.com 501521658 -1700, accessed 05/03/2011.

75. Rodgman, A. and C.R. Green: Toxic chemicals in cigarette mainstream smoke hazard and hoopla; in: Cigarette risk and the potential for risk reduction; Proceedings of the 2002 CORESTA Congress, New Orleans, LA, pp. 2-52, see www.rjitdocs.com 526909637 -9687, accessed 05/03/2011; Beitr. 
Tabakforsch. Int. 20 (2003) 481-545.

76. Rodgman, A. and T.A. Perfetti: The chemical components of tobacco and tobacco smoke; CRC Press, Boca Raton, FL (2008).

77. Rodgman, A., C.J. Smith, and T.A. Perfetti: The composition of cigarette smoke: A retrospective, with emphasis on polycyclic components; Human Exptl. Toxicol. 19 (2000) 573-595.

78. Roe, F.J.C.: Role of 3,4-benzopyrene in carcinogenesis by tobacco smoke condensate; Nature 194 (1962) 1089-1090.

79. Roe, F.J.C.: Role of 3,4-benzopyrene in carcinogenesis by tobacco smoke condensate. Acta Unio Internat Contra Cancrum 19 (1963) 730.

80. Schlotzhauer, W.S., E.B. Higman, and I. Schmeltz: Products from pyrolysis of tobacco extracts; in: The chemistry of tobacco and tobacco smoke, edited by I. Schmeltz, Plenum Publishing Corp., New York, NY (1972) 69.

81. Schumacher, J.N.: Maryland tobacco; R\&DR, 1982, No. 4, February 12, see www.rjrtdocs.com 501006126 -6151, accessed 05/03/2011; Flavor composition of Maryland tobacco; $36^{\text {th }}$ Tobacco Chemists' Research Conference, Program Booklet and Abstracts, Vol. 36, Paper No. 25, 1982, p. 13; CORESTA 1982 Symp., Winston-Salem, NC, CORESTA Inf. Bull., Spec. Edition 1982: Paper S11, 21-22; Beitr. Tabakforsch. Int. 12 (1982) 271-278.

82. Schumacher, J.N. and L.L. Vestal: Turkish tobacco. Isolation and identification of some components of the essential oil of Turkish tobacco dust; RDR, 1962, No. 18, June 25, see www.rjrtdocs.com 500938952-8981, accessed 05/03/2011.

83. Schumacher, J.N. and L.L. Vestal: Isolation and identification of some components of Turkish tobacco; $27^{\text {th }}$ Tobacco Chemists' Research Conference, Program Booklet and Abstracts, Vol. 27, Paper No. 47, 1973, p. 31; Tob. Sci. 18 (1974) 43-48.

84. Shear, M.J. and J. Leiter: Studies in carcinogenesis. XVI. Production of subcutaneous tumors in mice by miscellaneous polycyclic compounds; J. Natl. Cancer Inst. 2 (1941) 241-258.

85. Stedman, R.L: The chemical composition of tobacco and tobacco smoke; Chem. Rev. 68 (1968) 153-207.

86. Stepanov, I., P.W. Villalta, A. Knezevich, J. Jensen, D. Hatsukami and S.S. Hecht: Analysis of 23 polycyclic aromatic hydrocarbons in smokeless tobacco by gas chromatography-mass spectrometry; Chem. Res. Toxicol. 23 (2010) 66-73.

87. Tso, T.C.: Production, physiology, and biochemistry of tobacco plant; Ideals, Inc., Beltsville, MD (1990).

88. Tso, T.C.: Production, physiology, and biochemistry of tobacco plant; Ideals, Inc., Beltsville, MD (1990), see Chapter 27, Table 27.1, Compounds reported in leaf tobacco, pp. 596-600.

89. US Public Health Service (USPHS): Reducing the health consequences of smoking. 25 Years of progress. A report of the Surgeon General; DHHS Publ. No. (PHS) 89-8411 (1989).

90. Wakeham, H.: Recent trends in tobacco and tobacco smoke research; Symposium on the Composition of Tobacco and Tobacco Smoke, Am. Chem. Soc. Mtg., Washington, DC (1971); in: The chemistry of tobacco and tobacco smoke, edited by I. Schmeltz, Plenum Press, New York, NY (1972) 1-20.

91. Weeks, W.W.: Chemistry of tobacco constituents influencing flavor and aroma; Recent Adv. Tob. Sci. 11 (1985) 175-200.

92. Williams, R.W. and Science Information Division, Research and Development: Constituents reported in tobacco and tobacco smoke; R.J. Reynolds Tobacco Company, Winston-Salem, NC, 1997, pp. 1-134; Inhouse data base for chemical compounds isolated from tobacco and tobacco smoke/aerosol; R\&DM, 1989, No. 30, February 2, see www.rjrtdocs.com 508885321 5341, accessed 05/03/2011; see also www.rjrtdocs.com $517550972-1193$, accessed 05/03/2011; see also http://legacy.library.ucsf.edu/tid/aqf91c00, accessed 05/03/2011; Chemical compounds isolated from tobacco and tobacco smoke/aerosol. II. CHEM database system modifications; R\&DM, 1990, No. 9, January 29, see www.rjrtdocs.com 508381184 -1197, accessed 05/03/2011.

\section{Corresponding author:}

Thomas A. Perfetti

Perfetti and Perfetti, LLC

2116 New Castle Drive

Winston-Salem, NC, 27103-5750

USA 